\title{
Article
}

\section{In Vitro Anticancer Potential of Jasione montana and Its Main Components against Human Amelanotic Melanoma Cells}

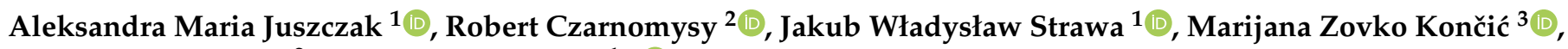 \\ Krzysztof Bielawski ${ }^{2}$ and Michał Tomczyk ${ }^{1, *}$ (D) \\ 1 Department of Pharmacognosy, Faculty of Pharmacy with the Division of Laboratory Medicine, \\ Medical University of Białystok, ul. Mickiewicza 2a, 15-230 Białystok, Poland; \\ aleksandra.juszczak@umb.edu.pl (A.M.J.); jakub.strawa@umb.edu.pl (J.W.S.) \\ 2 Department of Synthesis and Technology of Drugs, Faculty of Pharmacy with the Division of Laboratory \\ Medicine, Medical University of Białystok, ul. Kilińskiego 1, 15-089 Białystok, Poland; \\ robert.czarnomysy@umb.edu.pl (R.C.); kbiel@umb.edu.pl (K.B.) \\ 3 Department of Pharmacognosy, Faculty of Pharmacy and Biochemistry, University of Zagreb, Maruliceev trg \\ 20/II, 10000 Zagreb, Croatia; mzovko@pharma.hr \\ * Correspondence: michal.tomczyk@umb.edu.pl; Tel.: +48-85-748-56-94
}

check for updates

Citation: Juszczak, A.M.; Czarnomysy, R.; Strawa, J.W.; Zovko Končić, M.; Bielawski, K.; Tomczyk, M. In Vitro Anticancer Potential of Jasione montana and Its Main Components against Human Amelanotic Melanoma Cells. Int. J. Mol. Sci. 2021, 22, 3345. https:// doi.org/10.3390/ijms22073345

Academic Editor: Gi-Young Kim

Received: 15 March 2021

Accepted: 23 March 2021

Published: 25 March 2021

Publisher's Note: MDPI stays neutral with regard to jurisdictional claims in published maps and institutional affiliations.

Copyright: (c) 2021 by the authors. Licensee MDPI, Basel, Switzerland. This article is an open access article distributed under the terms and conditions of the Creative Commons Attribution (CC BY) license (https:// creativecommons.org/licenses/by/ $4.0 /)$.
Abstract: Jasione montana L. (Campanulaceae) is used in traditional Belarusian herbal medicine for sleep disorders in children, but the chemical composition and biological activity have not been investigated. In this study, the activities of J. montana extracts, their fractions and main compounds were evaluated in amelanotic melanoma C32 (CRL-1585) cells and normal fibroblasts (PCS-201-012). The extracts and fractions were analyzed using liquid chromatography-photodiode array detectionelectrospray ionization-mass spectrometry (LC-PDA-ESI-MS/TOF) to characterize 25 compounds. Further, three major and known constituents, luteolin (22) and its derivatives such as 7-O-glucoside (12) and 7-O-sambubioside (9) were isolated and identified. The cytotoxic activities against fibroblasts and the amelanotic melanoma cell line were determined using the fixable viability stain (FVS) assay. The influence of diethyl ether $\left(\mathrm{Et}_{2} \mathrm{O}\right)$ fraction (JM4) and 22 on apoptosis induction was investigated using an annexin $\mathrm{V}$ binding assay. The obtained results showed significant cytotoxicity of JM4 and 22 with $\mathrm{IC}_{50}$ values of $119.7 \pm 3.2$ and $95.1 \pm 7.2 \mu \mathrm{g} / \mathrm{mL}$, respectively. The proapoptotic potential after 22 treatment in the $\mathrm{C} 32$ human amelanotic melanoma cell line was comparable to that of vinblastine sulfate (VLB), detecting $29.2 \pm 3.0 \%$ apoptotic cells. Moreover, 22 displayed less necrotic potential against melanoma cells than VLB. In addition, the influences of JM4 and 22 on the dysfunction of the mitochondrial membrane potential (MMP), cell cycle and activity of caspases 3, 8, 9, and 10 were established. The effects of JM4 on MMP change $(74.5 \pm 3.0 \%$ of the cells showed a reduced MMP) corresponded to the results obtained from the annexin V binding assay and activation of caspase-9. JM4 and 22 displayed a significant impact on caspase-9 $(40.9 \pm 2.4 \%$ of the cells contained active caspase-9 after JM4 treatment and $16.6 \pm 0.8 \%$ after incubation with 22 ) and the intrinsic (mitochondrial) apoptotic pathway. Moreover, studies have shown that JM4 and 22 affect the activation of external apoptosis pathways by inducing the caspase- 8 and caspase- 10 cascades. Thus, activation of caspase- 3 and DNA damage via external and internal apoptotic pathways were observed after treatment with JM4 and 22. The obtained results suggest that J. montana extracts could be developed as new topical preparations with potential anticancer properties due to their promising cytotoxic and proapoptotic potential.

Keywords: Jasione montana; Campanulaceae; flavonoids; luteolin derivatives; fibroblasts; melanoma

\section{Introduction}

Skin cancers are the most common type of human cancer, with dramatically increasing incidence and mortality rates. The World Health Organization (WHO, Geneva, Switzerland) reports that globally, approximately 3 million skin cancers occur annually, of which less than 
$6 \%$ are melanomas [1]. Cutaneous malignant melanoma (CMM) developed by transformed melanocytes proliferating from the basal area of the epidermis, is the most aggressive form of diagnosed skin cancer [2,3]. Even though the incidence of melanoma is relatively low, its mortality is the highest among all skin cancers [4]. Although several new drugs have been developed over the last 10 years that have greatly improved the prognosis of patients with metastatic melanoma, many patients do not show a lasting response to these treatments [5]. Treatment with natural compounds and preparations based on plant materials have been increasingly used among patients with various neoplasms [6-8], and natural product-based treatments for melanoma are constantly being researched $[9,10]$.

Jasione montana L., commonly known as Sheep's bit scabious, is one of 16 representatives of the genus Jasione L. (Campanulaceae). The presence of J. montana outside of Europe, the Scandinavian Peninsula, Great Britain, and Ireland has been established, inter alia, in Morocco, Tunisia, Algeria, Russia, and Turkey, as well as in the northeastern region of the United States. It is a biennial plant, or occasionally, an annual plant, mainly found in warmer, sunny or semiarid places in lowland and upland regions. The determining factors for the distribution of $J$. montana are the temperature and average precipitation per year [11,12]. J. montana has been recognized as a garden plant [11]. Ethnopharmacological reports regarding this traditional Belarusian herbal medicine state that $J$. montana is used to treat sleep disorders in children, although its biological activity has not yet been assessed [13]. The available scientific literature on J. montana is scarce, and little is known about its phytochemical composition. A previous study of the aerial parts of J. montana established the presence of the bioactive flavonoid luteolin [14]. Taking these aspects into consideration, a detailed phytochemical analysis and characterization of the J. montana aerial parts was undertaken. Furthermore, the activities of the extracts, their fractions and isolated compounds against a human amelanotic melanoma cell line were investigated.

\section{Results}

\subsection{LC-ESI-MS Analysis of Extracts JM1-JM3 and Fractions JM4-JM6}

The phytochemical analysis, based on liquid chromatography-photodiode array detection-electrospray ionization-mass spectrometry (LC-PDA-ESI-MS/TOF) technique, results of the extracts $\left(\mathrm{H}_{2} \mathrm{O}, \mathrm{JM1} ; 50 \% \mathrm{MeOH}, \mathrm{JM} 2 ; \mathrm{MeOH}, \mathrm{JM} 3\right)$, and their fractions $\left(\mathrm{Et}_{2} \mathrm{O}\right.$, JM4; EtOAc, JM5; $n-\mathrm{BuOH}$, JM6) revealed 25 polyphenolic compounds. Extraction of the raw material with $\mathrm{MeOH}$ (JM3) resulted in a high content of free aglycones [peaks 22-25], among which luteolin (22) was the dominant peak. The second most represented compound was luteolin 7-O-glucoside (12). On the other hand, JM1 and JM2 were rich in glycosides, and the hydromethanolic extractant was the more efficient of the two solutions. The studied fractions (JM4-JM6) were characterized by the selectivity of the extraction process for specific groups of compounds. JM4 turned out to be rich in aglycones with a dominance of 22 as well as apigenin (23) and 12. Moreover, $p$-coumaric acid and its derivatives were also present in this faction [peaks 3, 10]. An absorption maximum at $310 \mathrm{~nm}$ in the ultravioletvisible (UV-VIS) spectrum is characteristic for these types of compounds. Compound 12 was also significantly dominated in the JM5 fraction. The presence of di- and triglycosides was also revealed [peaks 9, 14, 15]. These compound structures were suggested based on the loss of fragments $[\mathrm{M}-162 \pm \mathrm{H}]^{+/-},[\mathrm{M}-146 \pm \mathrm{H}]^{+/-}$, and $[\mathrm{M}-132 \pm \mathrm{H}]^{+/-}$, which correspond to $O$-hexose, $\mathrm{O}$-pentose, and $\mathrm{O}$-deoxyhexose, respectively. Moreover, aglycones substituted with a linear glycoside molecule [peaks 9, 14] as well as disubstituted compounds were present in the JM5 fraction [peak 15]. JM6 consisted of a mixture of flavonoid glycosides and was devoid of free aglycones. The LC-MS analysis is summarized in Table 1 and Supplementary Figures S1 and S2. 
Table 1. Liquid chromatography-mass spectrometry (LC-MS) analysis of extracts/fractions (JM1-JM6) from Jasione montana.

\begin{tabular}{|c|c|c|c|c|c|}
\hline Peak/Compound & Rt (min) & UV-VIS Maxima (nm) & {$[\mathbf{M}-\mathbf{H}]^{-}$Ions $(\mathrm{m} / z)$} & {$[\mathbf{M}-\mathbf{H}]^{+}$Ions $(m / z)$} & Identified Compounds \\
\hline 1 & 4.60 & 260 & $191,217,235$ & $86,136,276$ & Unknown \\
\hline 2 & 14.53 & 260,294 & $109,153,277$ & $93,137,213,248$ & Unknown \\
\hline 3 & 19.29 & $256,310 \mathrm{sh}$ & 93,183 & 94,302 & $p$-coumaroyl acid derivatives \\
\hline 4 & 20.79 & 268,330 & 565,771 & $302,538,773$ & Unknown \\
\hline 5 & 21.61 & 272,330 & 593 & $415,432,595$ & Flavonoid derivatives \\
\hline 6 & 22.53 & 268,336 & 609 & $287,449,611$ & Luteolin O-hex-hex \\
\hline 7 & 23.40 & 268,338 & 563,741 & $287,449,565,743$ & Luteolin O-hex-pent-hex \\
\hline 8 & 24.41 & 268,340 & 609 & $287,449,611$ & Luteolin O-hex-hex \\
\hline 9 & 25.59 & 268,348 & 285,579 & $287,449,581$ & Luteolin 7-O-sambubioside (s) \\
\hline 10 & 25.87 & 310 & 119,162 & $91,119,147,165$ & $p$-coumaric acid (s) \\
\hline 11 & 26.11 & 268,338 & 593 & $271,433,595$ & Apigenin O-hex-hex \\
\hline 12 & 26.84 & $258,266,348$ & 447,895 & 287,449 & Luteolin 7-O-glucoside (s) \\
\hline 13 & 26.99 & 268,326 & 593 & $287,449,595$ & Luteolin O-hex-deoxyhex \\
\hline 14 & 27.46 & $250,268,336$ & $285,447,609,755$ & $287,449,611,757$ & Luteolin O-hex-hex-deoxyhex \\
\hline 15 & 27.85 & 268,330 & 269,563 & $271,418,565$ & Apigenin $O$-deoxyhex-O-deoxyhex \\
\hline 16 & 28.76 & 268,335 & $285,447,579,769$ & $287,449,581,771$ & Luteolin O-hex-pent-feruloyl \\
\hline 17 & 29.27 & 268,330 & 285,431 & 286,433 & Flavonoid derivatives \\
\hline 18 & 29.45 & 268,336 & 285,447 & 287,449 & Luteolin O-hex \\
\hline 19 & 30.17 & 268,284 & 431 & $301,419,571$ & Flavonoid derivatives \\
\hline 20 & 30.53 & $268,300 \mathrm{sh}, 340$ & 285,447 & 287,449 & Luteolin O-hex \\
\hline 21 & 32.36 & 270,324 & 299,461 & 331,463 & Tricin O-pent \\
\hline 22 & 34.38 & $256,266,348$ & 285 & 287 & Luteolin (s) \\
\hline 23 & 36.23 & $268,295 \mathrm{sh}, 340$ & 269 & 271 & Apigenin (s) \\
\hline 24 & 36.35 & $270,300 \mathrm{sh}, 349$ & 329 & 331 & Tricin (s) \\
\hline 25 & 36.54 & $268,300 \mathrm{sh}, 344$ & 299 & 301 & Chrysoeriol (s) \\
\hline
\end{tabular}

sh—peak shoulder; bold—most abundantion; s—reference substance; hex-hexose, pent-pentose, deoxyhex—deoxyhexose.

\subsection{Identification of the Isolated Compounds $\mathbf{9}, \mathbf{1 2}$ and $\mathbf{2 2}$}

As a result of exhaustive multistep chromatographic isolation processes, three chromatographically homogeneous known compounds $(\mathbf{9}, \mathbf{1 2}$, and 22) were isolated from the obtained JM4-JM6 fractions. The identification of those compounds was carried out on the basis of $R_{\mathrm{f}}$ values, products of acid hydrolysis and spectroscopic methods (ultraviolet (UV) spectroscopy, nuclear magnetic resonance $\left({ }^{1} \mathrm{H}\right.$ NMR,$\left.{ }^{13} \mathrm{C} \mathrm{NMR}\right)$, mass spectrometry (MS)). The spectral data of all compounds were identical to the available literature data. The spectral properties of compounds $\mathbf{9 , 1 2}$ and $\mathbf{2 2}$ were verified by comparison of its spectral data with those previously described in the literature. Isolated compounds were identified as luteolin 7-O- $\beta$-D-xylosyl-(1-2)- $\beta$-D-glucoside (luteolin 7-O-sambubioside, 9), luteolin 7-O- $\beta$-D-glucoside (cynaroside, 12) and luteolin (22) (Figure 1) [15-17] (Supplementary Figures S3-S8).<smiles>[R]c1cc(O)c2c(=O)cc(-c3ccc(O)c(O)c3)oc2c1</smiles>

Figure 1. Chemical structures of isolated compounds $\mathbf{9 , 1 2}$ and 22.

\subsection{Cytotoxicity Assay}

An MTT assay was performed separately for each sample for a preliminary assessment of the cytotoxic effects of JM1-JM6 and compounds 9, 12 and 22 on the viability of C32 and fibroblast cells. The MTT assay is among the most common methods for the evaluation 
of cell viability. However, several studies have shown inaccuracies that are inherent in the MTT method. Some studied plant extracts and polyphenols directly reduce the tetrazolium salt even in the absence of cells, which interferes with the MTT assay [18-20]. Additionally, the MTT assay has a limited operating range of compounds with a strong color that can be absorbed by the tested cells. Due to the imprecision of the MTT method, the fixable viability stain assay was chosen as an alternative to assess viability. C32 and fibroblast cells were treated with JM1-JM6, compounds 9, 12, 22 and vinblastine sulfate (VLB) at increasing concentrations $(10-300 \mu \mathrm{g} / \mathrm{mL})$ for $24 \mathrm{~h}$. The results are presented in Table 2 and Supplementary Figures S9-S12. The morphological profile of C32 melanoma cells after $24 \mathrm{~h}$ of incubation with JM4, 22 and VLB is shown in Figure 2. We observed dosedependent degradation of the cell membrane and a decrease in cell adhesion. Additionally, the number of cells in the treatment groups decreased compared with the untreated group, indicating inhibition of cell proliferation or induction of apoptosis. The highest activity was observed after treatment with compound 22 at a concentration of $25 \mu \mathrm{g} / \mathrm{mL}$. The fixable viability stain study showed that $\mathrm{C} 32$ cell viability was inversely proportional to the applied concentration of all tested compounds. The cytotoxic potential is expressed as a median inhibitory concentration $\left(\mathrm{IC}_{50}\right)$ value, where the $\mathrm{IC}_{50}$ value and cytotoxic activity value are inversely proportional. The tested extracts and compounds inhibited the viability of C32 cells in a dose-dependent manner. The $\mathrm{IC}_{50}$ values for some of the extracts and compounds were either similar (JM4 IC $\mathrm{I}_{50}=119.7 \mu \mathrm{g} / \mathrm{mL}$ ) to VLB $\left(\mathrm{IC}_{50}=148.5 \mu \mathrm{g} / \mathrm{mL}\right)$ or somewhat higher (e.g., JM6 $\left.\mathrm{IC}_{50}=215.7\right)$, while compound 22 had an $\mathrm{IC}_{50}$ value $(95.1 \mu \mathrm{g} / \mathrm{mL})$ even lower than that of VLB. The $\mathrm{IC}_{50}$ values of the other extracts were $>300 \mu \mathrm{g} / \mathrm{mL}$. The viability of the fibroblast cells under the influence of JM4 and 22 was higher than that of the C32 cells. In the case of fibroblasts, the $\mathrm{IC}_{50}$ value for JM4 was above $300 \mu \mathrm{g} / \mathrm{mL}$, and that for compound 22 was $194.1 \pm 4.4 \mu \mathrm{g} / \mathrm{mL}$ (Supplementary Figure S13).

Table 2. $\mathrm{IC}_{50}$ of viability of CRL-1585 human amelanotic melanoma cells treated for $24 \mathrm{~h}$ with different concentrations of JM1-JM6 and isolated compounds 9, 12, 22 from J. montana. Mean values $\pm \mathrm{SD}$ from three independent experiments done in duplicate are presented. ( $\mathrm{IC}_{50}$ value in $\mu \mathrm{g} / \mathrm{mL}$ ).

\begin{tabular}{cc}
\hline Sample & IC $_{\mathbf{5 0}}[\boldsymbol{\mu g} / \mathbf{m L}]$ \\
\hline JM1 & $>300$ \\
JM2 & $>300$ \\
JM3 & $>300$ \\
JM4 & $119.7 \pm 3.2$ \\
JM5 & $>300$ \\
JM6 & $215.7 \pm 21.2$ \\
Compound 9 & $>300$ \\
Compound 12 & $>300$ \\
Compound 22 & $95.1 \pm 7.2$ \\
VLB & $148.5 \pm 7.7$ \\
\hline
\end{tabular}
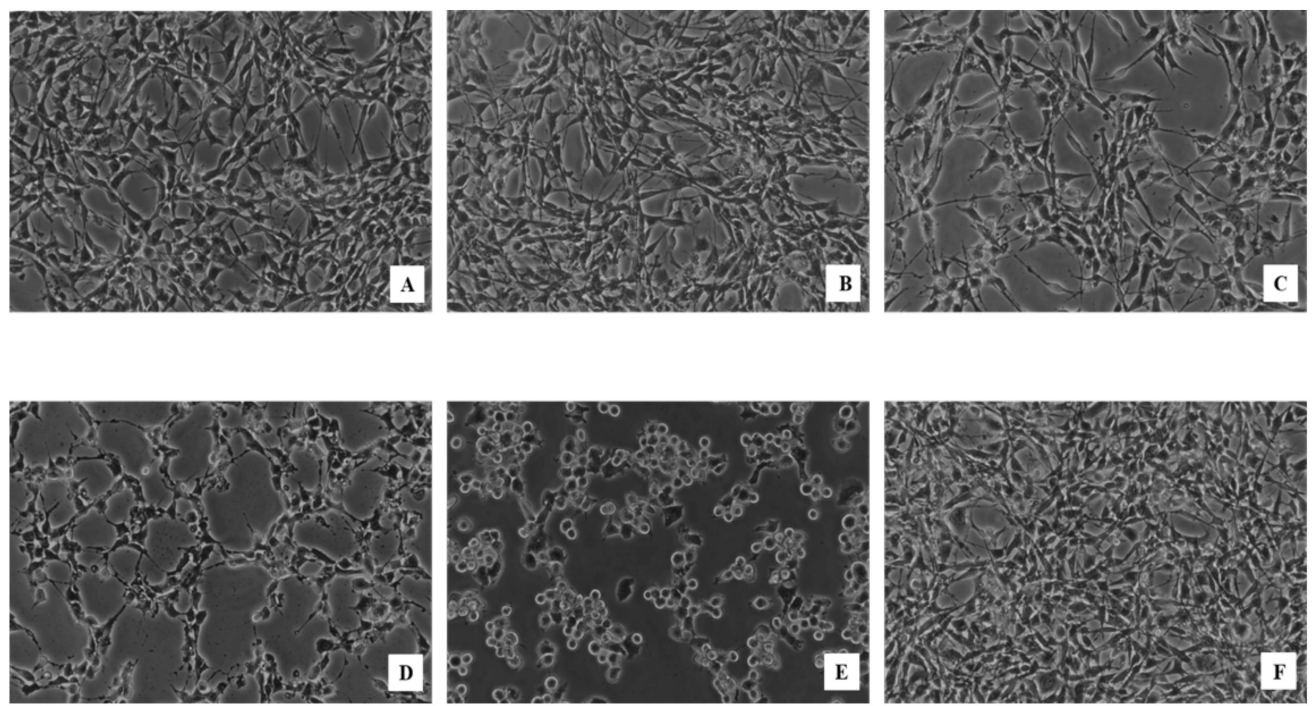

Figure 2. Morphological profile of C32 melanoma cells after $24 \mathrm{~h}$ of incubation with JM4 in concentration $25 \mu \mathrm{g} / \mathrm{mL}$ 
The obtained results suggested that JM4 and compound 22 were the most active against human amelanotic melanoma C32 cells. Due to the high activity of the mentioned fraction and compound, JM4 and $\mathbf{2 2}$ were submitted for further study. Notably, based on the content of compound $\mathbf{2 2}$ in JM4, it can be concluded that this compound is dominantly responsible for the observed effects of the JM4 fraction on C32 cells.

\subsection{Alteration of C32 Cell Cycle Progression by JM4 and 22}

The results demonstrated the differences between the investigated JM4 and compound 22, their concentration and the control group with respect to the percentage of accumulated C32 cells in different cell cycle phases after $24 \mathrm{~h}$ incubation (Figures 3 and 4). JM4 at a concentration of $100 \mu \mathrm{g} / \mathrm{mL}$ led to the accumulation of C32 cells in the $\mathrm{S}$ and G2/M phases. Simultaneously, the population of C32 cells in G1 phase after treatment with JM4 was meaningfully reduced. The percentage of C32 cells in G2 phase increased from $6.1 \pm 0.6 \%$ in the untreated control group to $30.1 \pm 1.8 \%$ after treatment with JM4 $(100 \mu \mathrm{g} / \mathrm{mL})$. However, this result was significantly lower than that in the case of VLB $(25 \mu \mathrm{g} / \mathrm{mL})$. Additionally, the percentage of C32 cells in G1 phase in the untreated control group decreased from $73.0 \pm 0.9 \%$ to $35.3 \pm 3.0 \%$ after incubation with $22(25 \mu \mathrm{g} / \mathrm{mL})$, and the percentage of C32 cells in G2/M phase increased from $6.1 \pm 0.6 \%$ to $14.6 \pm 1.5 \%$ after treatment with $22(25 \mu \mathrm{g} / \mathrm{mL})$.

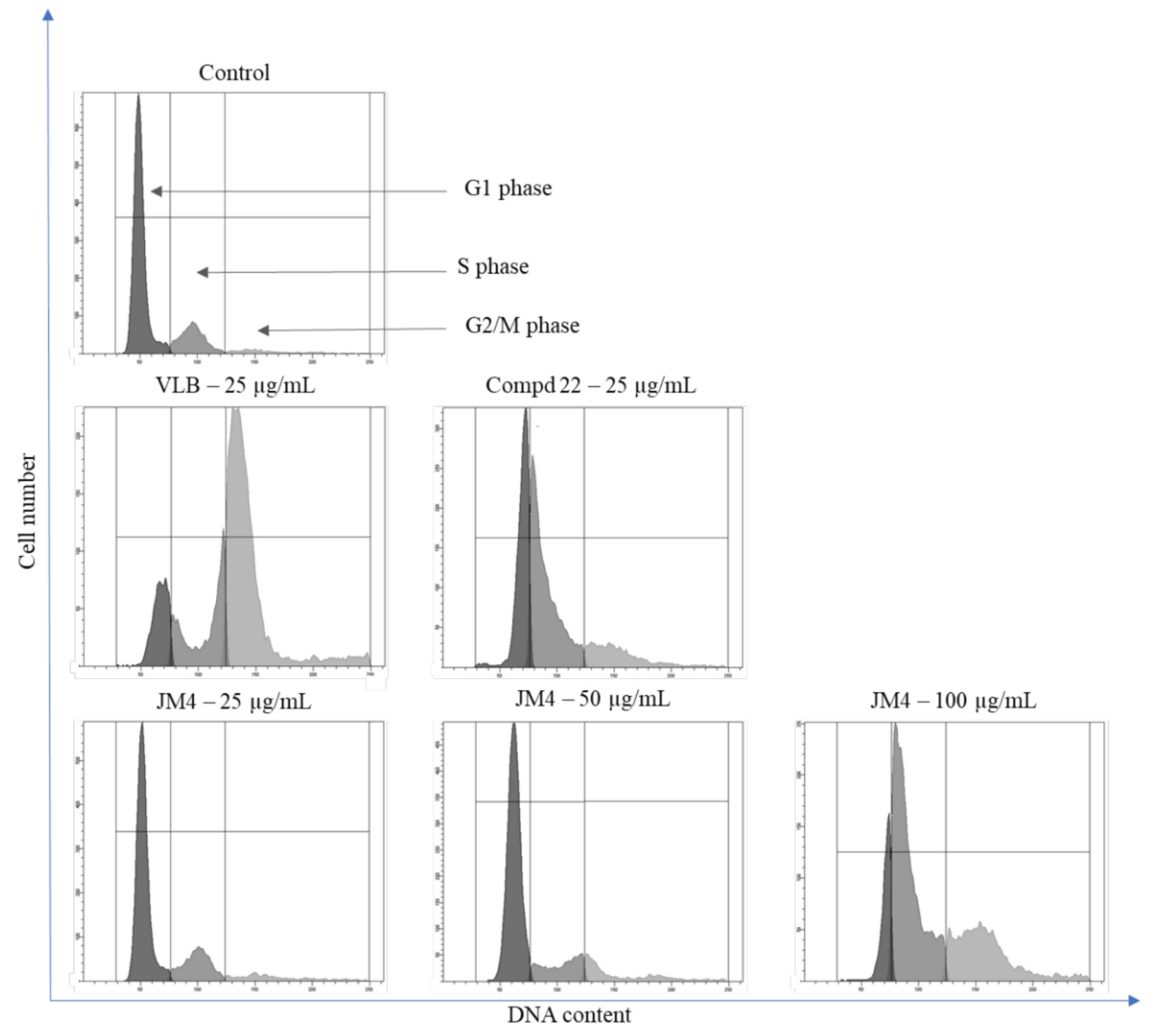

Figure 3. Flow cytometric analysis of cell cycle of C32 melanoma cells after 24 h of incubation with JM4 (25, 50, 100 $\mu \mathrm{g} / \mathrm{mL})$, $22(25 \mu \mathrm{g} / \mathrm{mL})$ and vinblastine sulfate (VLB) $(25 \mu \mathrm{g} / \mathrm{mL})$ using propidium iodide (PI) staining.

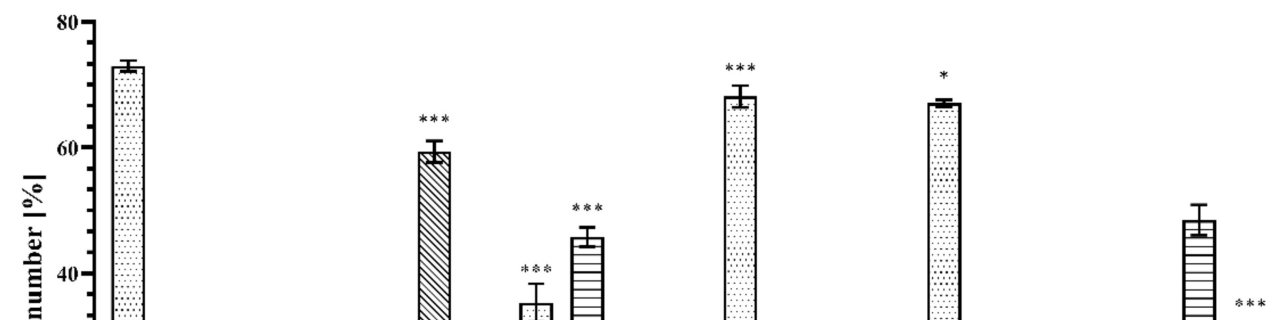


The obtained results suggested that the effects on C32 cell cycle arrest in the S and G2/M phases was not caused by the main component of the JM4 fraction, which is compound 22 (luteolin).

\subsection{The JM4 Fraction and Compound 22 Induce Apoptosis in Melanoma C32 Cells}

During programmed cell death, annexin $\mathrm{V}$ has a high affinity for phosphatidylserine (PS) when it is exposed to the extracellular environment. Hence, this assay is based on the externalization of PS on the cell membrane. Additionally, propidium iodide (PI) was used to determine the number of necrotic cells, which confirms the integrity of the cell membrane [21,22]. The assay allows differentiability between viable cells (annexin V-/PI-) and early (annexin $\mathrm{V}-/ \mathrm{PI}+$ ) and late (annexin $\mathrm{V}+/ \mathrm{PI}+$ ) apoptotic cells, as well as necrotic cells (annexin $\mathrm{V}-/ \mathrm{PI}+$ ).

An apoptosis study was performed to determine the mode of cell death provoked by JM4 and 22. The results are presented in Figures 5 and 6. This analysis demonstrated that both tested samples, JM4 and 22, significantly induced programmed death in C32 cells in comparison with the untreated control group, where $91.2 \pm 1.0 \%$ viable cells and $7.3 \pm 1.3 \%$ apoptotic cells were observed. Fraction JM4 $(100 \mu \mathrm{g} / \mathrm{mL})$ displayed the most significant proapoptotic effect after $24 \mathrm{~h}$ of incubation, where we detected $44.2 \pm 1.0 \%$ viable cells and $51.5 \pm 1.7 \%$ apoptotic cells. Nevertheless, with increasing concentration, a significant increase in the percentage of necrotic cells $(4.3 \pm 2.6 \%$ of necrotic cells after incubation with JM4 $(100 \mu \mathrm{g} / \mathrm{mL}))$ was shown which may suggest the toxic activity of JM4 at higher concentrations. Compound $22(25 \mu \mathrm{g} / \mathrm{mL})$ and VLB displayed similar proapoptotic effect after $24 \mathrm{~h}$ of incubation, where we detected $29.2 \pm 3.0 \%$ apoptotic cells after treatment with 22, and $27.4 \pm 1.0 \%$ apoptotic cells after treatment with VLB. However, VLB exhibited two times higher necrotic potential $(4.2 \pm 1.0 \%$ necrotic cells after incubation with VLB $(25 \mu \mathrm{g} / \mathrm{mL}))$.

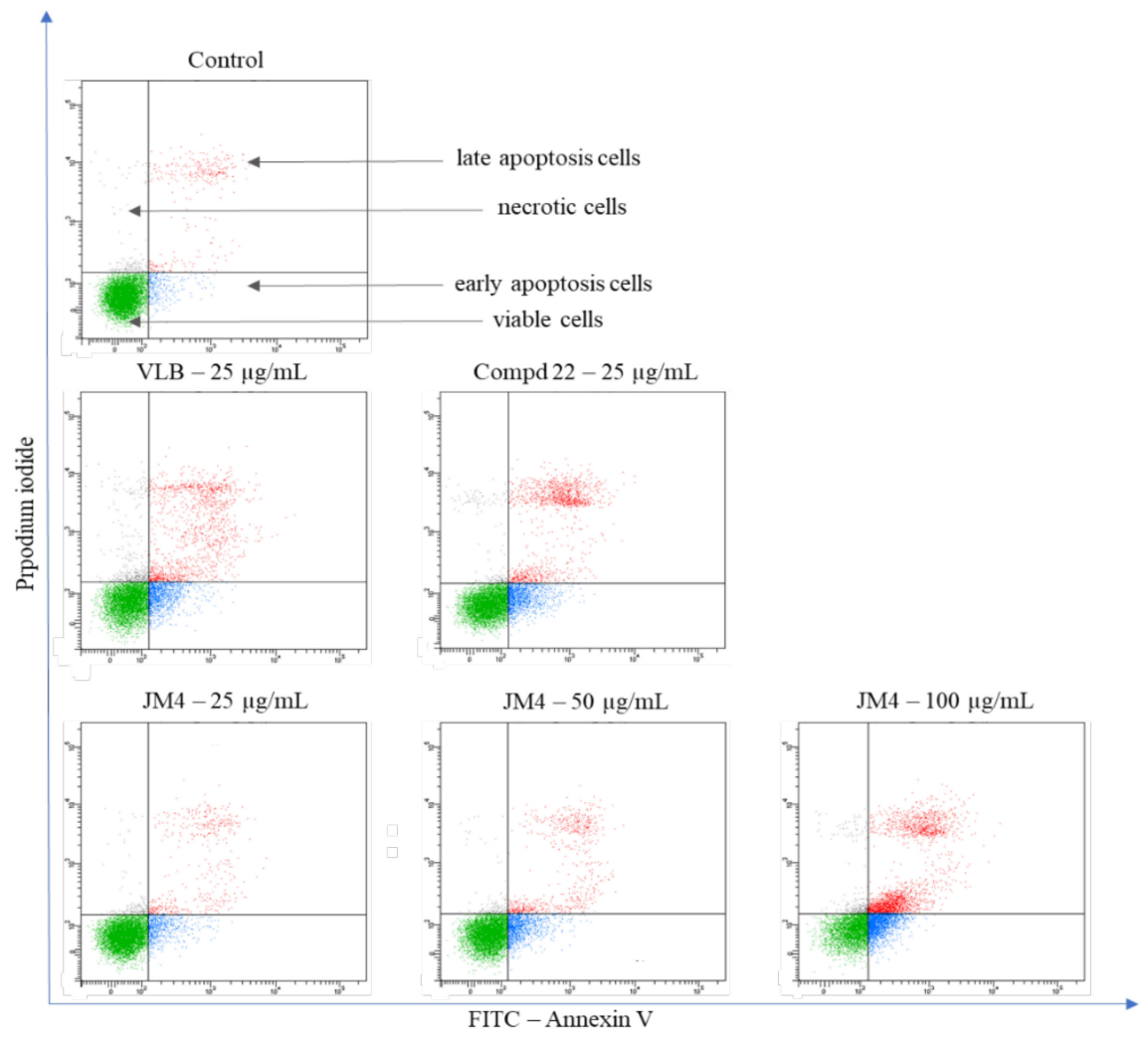

Figure 5. Flow cytometric analysis of C32 melanoma cells after incubation with JM4 (25, 50, $100 \mu \mathrm{g} / \mathrm{mL}), 22(25 \mu \mathrm{g} / \mathrm{mL})$ and vinblastine sulfate (VLB) $(25 \mu \mathrm{g} / \mathrm{mL})$ for $24 \mathrm{~h}$ and subsequent staining with Annexin V and propidium iodide (PI). 


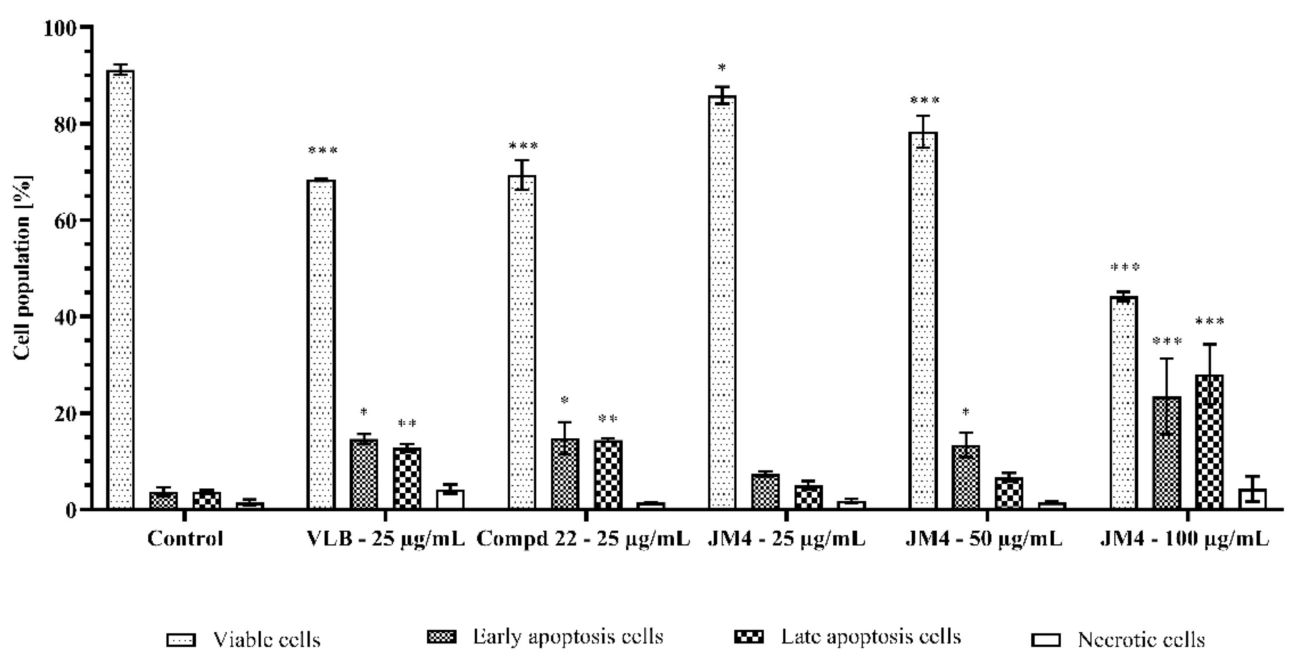

Figure 6. Percentage of viable C32 melanoma cells, early and late apoptosis cells, and necrotic cells, after $24 \mathrm{~h}$ of incubation with JM4 $(25,50,100 \mu \mathrm{g} / \mathrm{mL}), 22(25 \mu \mathrm{g} / \mathrm{mL})$ and vinblastine sulfate (VLB) $(25 \mu \mathrm{g} / \mathrm{mL})$. Mean percentages from three independent experiments $(n=3)$ done in duplicate are presented. ${ }^{*} p<0.05$ versus control group, ${ }^{* *} p<0.01$ versus control group, ${ }^{* * *} p<0.001$ versus control group.

\subsection{Fraction JM4 and Compound 22 Induce Autophagy}

Autophagy contributes to the maintenance of internal cell homeostasis by preventing the accumulation of damaged cell organelles. The level of autophagy is directly proportional to the increase in cellular stress, which ultimately leads to programmed cell death $[23,24]$.

The Autophagy Assay, Red was carried out via flow cytometry to detect the level of autophagy in C32 cells after $24 \mathrm{~h}$ of incubation with JM4 and compound 22. The results, expressed as the change in intensity of induced autophagy in C32 cells versus the untreated control group, differed according to treatment type (JM4 vs. 22 vs. VLB) and concentrations (Figures 7 and 8). There were $94.5 \pm 1.0 \%$ nonautophagic cells and $4.8 \pm 0.8 \%$ autophagic cells in the untreated control group. The highest dose-dependent activity of the induced autophagy process among the investigated samples/concentrations was displayed after $24 \mathrm{~h}$ incubation with fraction JM4 $(100 \mu \mathrm{g} / \mathrm{mL})$, where we observed $60.2 \pm 1.6 \%$ nonautophagic cells and $38.6 \pm 1.6 \%$ of autophagic cells, which was twofold lower than in case of VLB. Significant activation of autophagy was observed after $24 \mathrm{~h}$ treatment with VLB $(25 \mu \mathrm{g} / \mathrm{mL}) ; 22.4 \pm 0.6 \%$ nonautophagic cells and $76.7 \pm 0.5 \%$ of autophagic cells. The significant dose-dependent increase in the percentage of autophagic cells after JM4 treatment may suggest that JM4 causes stress in cells and leads to the induction of programmed cell death. 


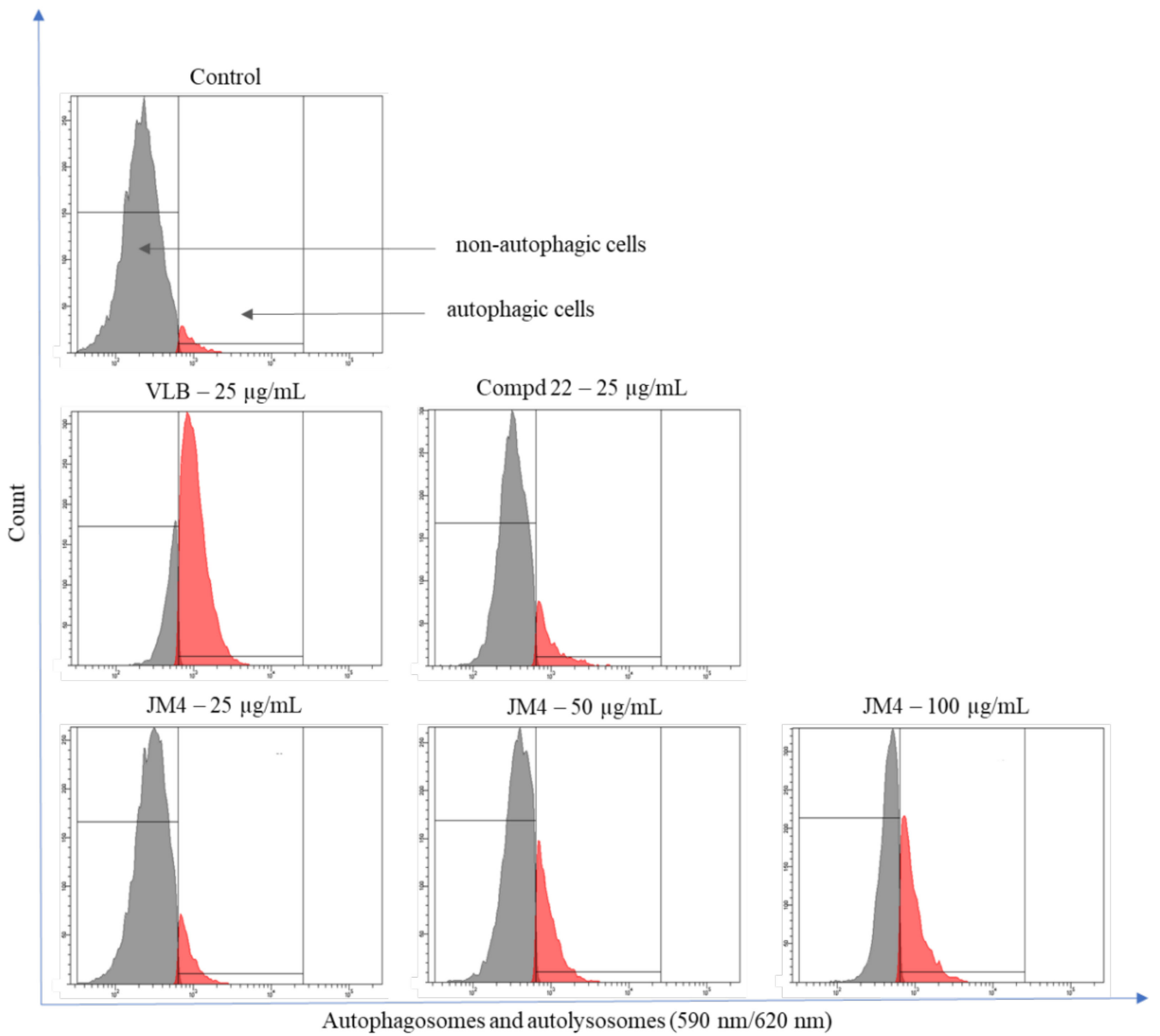

Figure 7. Autophagy induction in C32 melanoma cells measured by flow cytometry using Autophagy Probe (right—red histogram) compared to negative control cells (left—gray histogram) after $24 \mathrm{~h}$ incubation with JM4 (25, 50, 100 $\mu \mathrm{g} / \mathrm{mL}), 22$ $(25 \mu \mathrm{g} / \mathrm{mL})$ and vinblastine sulfate (VLB) $(25 \mu \mathrm{g} / \mathrm{mL})$.

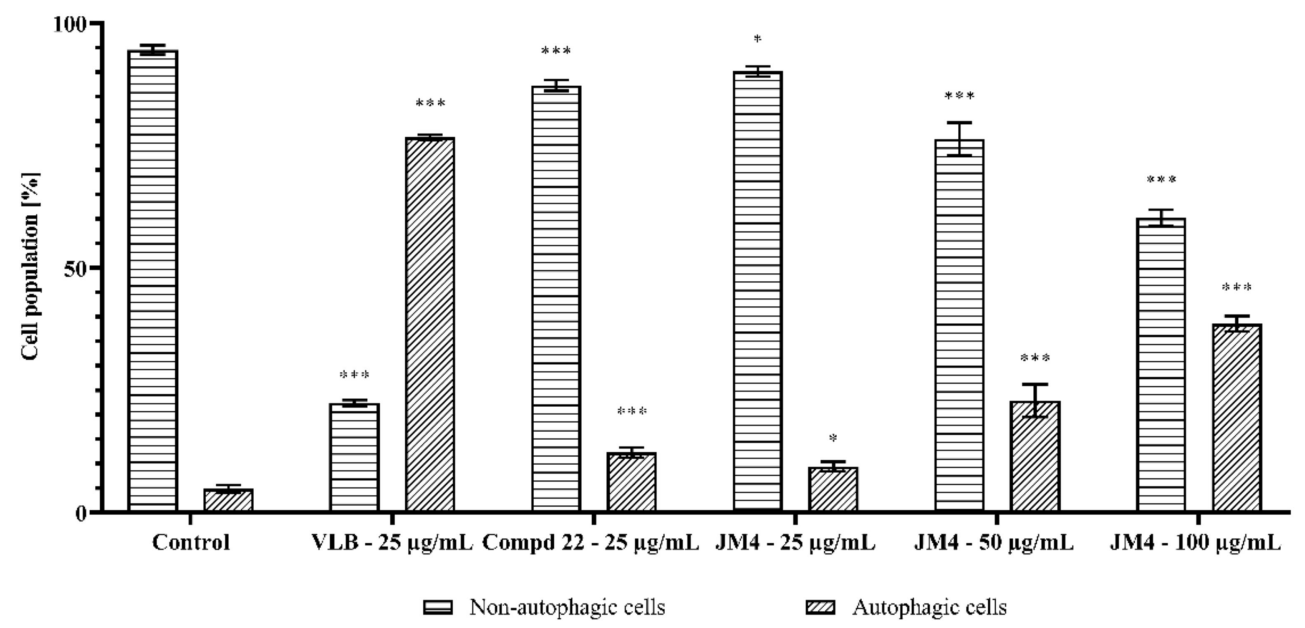

Figure 8. Percentage of nonautophagic and autophagic C32 melanoma cell population after $24 \mathrm{~h}$ incubation with JM4 (25, 50, $100 \mu \mathrm{g} / \mathrm{mL}), 22(25 \mu \mathrm{g} / \mathrm{mL})$ and vinblastine sulfate (VLB) $(25 \mu \mathrm{g} / \mathrm{mL})$. Mean percentage values from three independent experiments $(n=3)$ done in duplicate are presented. ${ }^{*} p<0.05$ versus control group, ${ }^{* *} p<0.001$ versus control group. 


\subsection{The Impact of Fraction JM4 and Compound 22 on Mitochondrial Membrane Potential (MMP)}

To evaluate the mechanism underlying intrinsic cellular apoptosis under the influence of JM4 and compound 22, staining with the fluorescent dye JC-1 was performed. Reduced mitochondrial membrane potential (MMP) is associated with the early stages of apoptosis as well as with the appearance of cytochrome $C$ in the cytosol [25-27]. As shown in Figures 9 and 10, JM4 caused a significant dose-dependent reduction in the MMP at the highest dose. We observed that $74.5 \pm 3.0 \%$ of the cells had a reduced MMP after $24 \mathrm{~h}$ incubation with JM4 $(100 \mu \mathrm{g} / \mathrm{mL})$, whereas the untreated control group had only a reduced MMP in $5.2 \pm 0.1 \%$ of the cells. JM4 at a concentration of $100 \mu \mathrm{g} / \mathrm{mL}$ led to a twofold higher percentage of cells with a reduced MMP than VLB $(34.1 \pm 3.0 \%)$. A weaker effect was displayed after $24 \mathrm{~h}$ of incubation with $22(25 \mu \mathrm{g} / \mathrm{mL})$, where we observed that $31.8 \pm 0.7 \%$ of the cells had a reduced MMP. The obtained results are in accordance with the results from the annexin $\mathrm{V}$ binding assay.

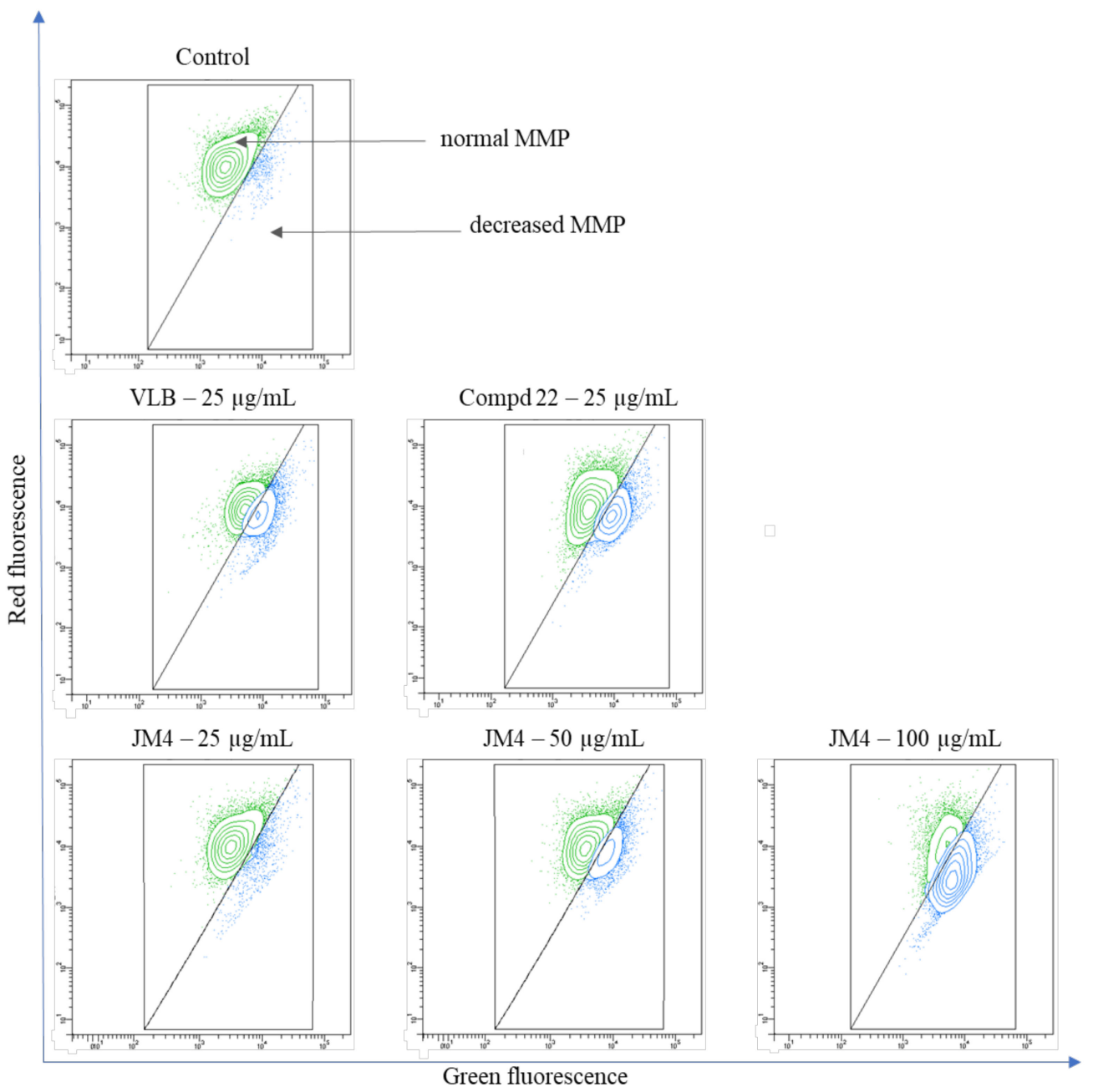

Figure 9. Fluorescence of C32 melanoma cells treated for $24 \mathrm{~h}$ with JM4 $(25,50,100 \mu \mathrm{g} / \mathrm{mL}), 22(25 \mu \mathrm{g} / \mathrm{mL})$ and vinblastine sulfate (VLB) $(25 \mu \mathrm{g} / \mathrm{mL})$ incubated with mitochondrial membrane potential probe JC-1. 


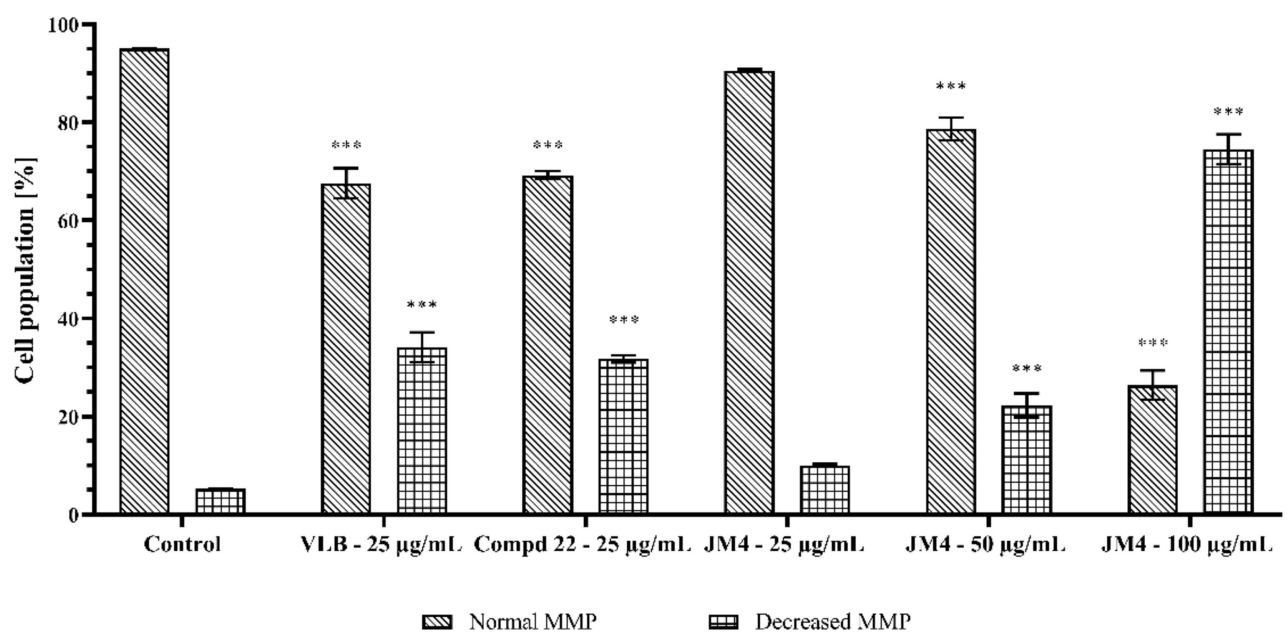

Figure 10. Percentage of $C 32$ melanoma cells with normal and decreased mitochondrial membrane potential (MMP) after $24 \mathrm{~h}$ incubation with JM4 $(25,50,100 \mu \mathrm{g} / \mathrm{mL}), 22(25 \mu \mathrm{g} / \mathrm{mL})$ and vinblastine sulfate (VLB) $(25 \mu \mathrm{g} / \mathrm{mL})$. Mean percentage values from three independent experiments $(n=3)$ done in duplicate are presented. ${ }^{* * *} p<0.001$ versus control group.

\subsection{Activation of Caspase-3, Caspase-8, Caspase-9, and Caspase-10}

Caspases play a crucial role in the activation of the apoptotic process. Activation of apical caspases (caspase-8 and caspase-10) leads to initiation of the external apoptotic pathway as well as activation of the effector caspase, caspase-3. In addition, the intrinsic (mitochondrial) apoptotic pathway is closely related to the activity of caspase-9, which is stimulated by a reduction in the MMP and plays an equally important role in the activation of caspase-3. Caspase-3 instructs the cell directly through apoptosis and DNA damage [28-30]. The influence of JM4 and compound 22 on the expression of caspases 3, 8,9 , and 10 in C32 cells is shown in Figures 11-18. The results proved that there was a significant increase in the levels of all caspases compared to the untreated control group after $24 \mathrm{~h}$ incubation with tested samples. The most significant effect of the activation of caspase- 8 , caspase-9, and caspase-10 was observed after incubation with JM4 $(100 \mu \mathrm{g} / \mathrm{mL})$, where $41.8 \pm 0.5 \%$ of cells had active caspase- $8,40.9 \pm 2.4 \%$ of cells had active caspase- 9 , and $43.7 \pm 1.1 \%$ of cells had active caspase-10. In all cases, the increases were almost twofold higher than after treatment with VLB. Compound $22(25 \mu \mathrm{g} / \mathrm{mL})$ displayed a slightly weaker impact on the activation of caspase-8, caspase-9, and caspase-10, with $20.2 \pm 1.5 \%, 16.6 \pm 0.8 \%$, and $15.4 \pm 0.7 \%$ of cells with the active respective caspase. According to these results, JM4 and 22 induce the external and intrinsic apoptotic pathways as well as the activation of caspase-3, and JM4 $(100 \mu \mathrm{g} / \mathrm{mL})$ is the strongest activator of caspase-3. After treatment with JM4, $74.9 \pm 4.0 \%$ of the cells had active caspase-3, in comparison with $4.2 \pm 1.3 \%$ of the cells in the untreated control group and $23.4 \pm 3.5 \%$ of the cells after treatment with VLB. These results were consistent with the previous hypothesis of the intrinsic mitochondrial apoptotic pathway. The results showed that one of the molecular mechanisms leading to apoptosis caused by JM4 is the activation of caspases in a dose-dependent manner. Our study confirmed that JM4 was the strongest activator of all the tested caspases. Increasing the JM4 concentration enhanced its cytotoxic properties and significantly increased the expression of caspase-3, which is responsible for DNA damage. 


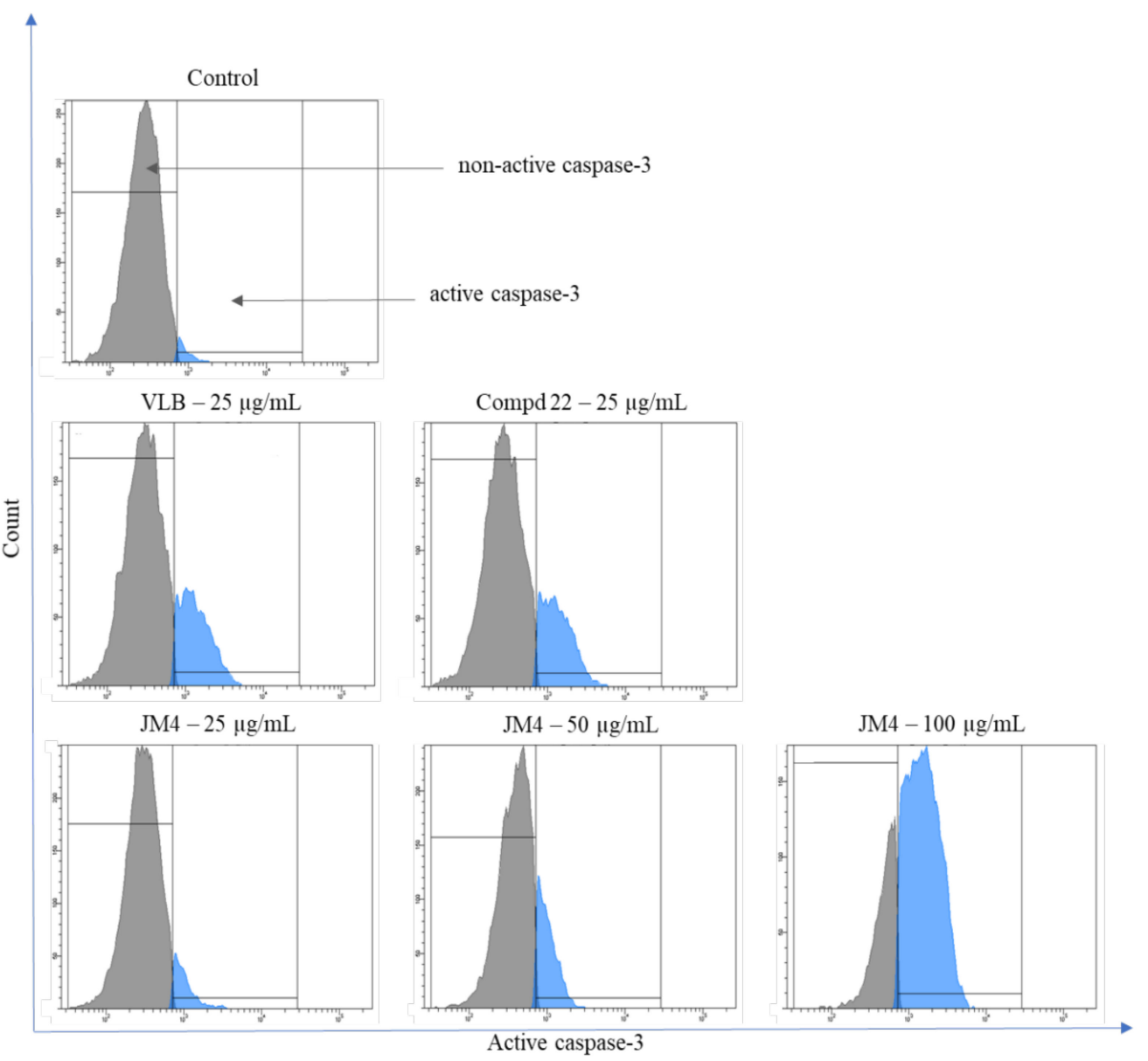

Figure 11. Flow cytometric analysis of populations C32 melanoma cells treated for $24 \mathrm{~h}$ with JM4 (25, 50, $100 \mu \mathrm{g} / \mathrm{mL}), 22$ $(25 \mu \mathrm{g} / \mathrm{mL})$ and vinblastine sulfate (VLB) $(25 \mu \mathrm{g} / \mathrm{mL})$ for active caspase- 3 .

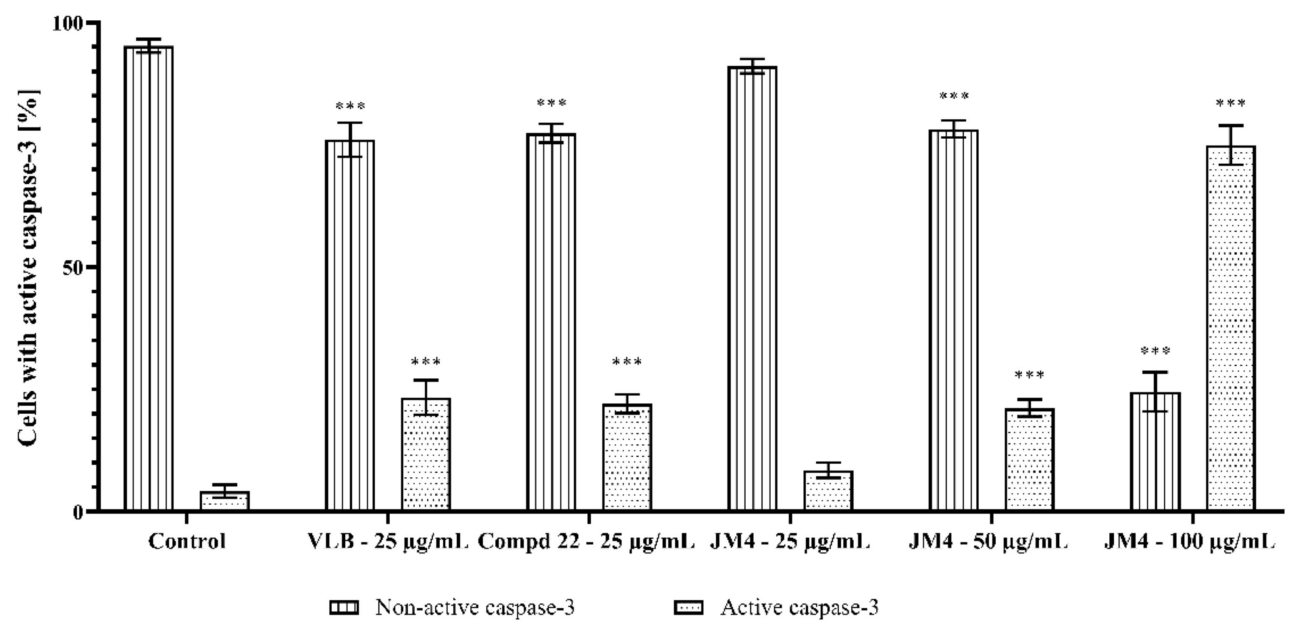

Figure 12. Percentage of C32 melanoma cells with nonactive and active caspase- 3 after 24 h incubation with JM4 (25, 50, $100 \mu \mathrm{g} / \mathrm{mL}), 22(25 \mu \mathrm{g} / \mathrm{mL})$ and vinblastine sulfate (VLB) $(25 \mu \mathrm{g} / \mathrm{mL})$. Mean percentage values from three independent experiments $(n=3)$ done in duplicate are presented. ${ }^{* * *} p<0.001$ versus control group. 


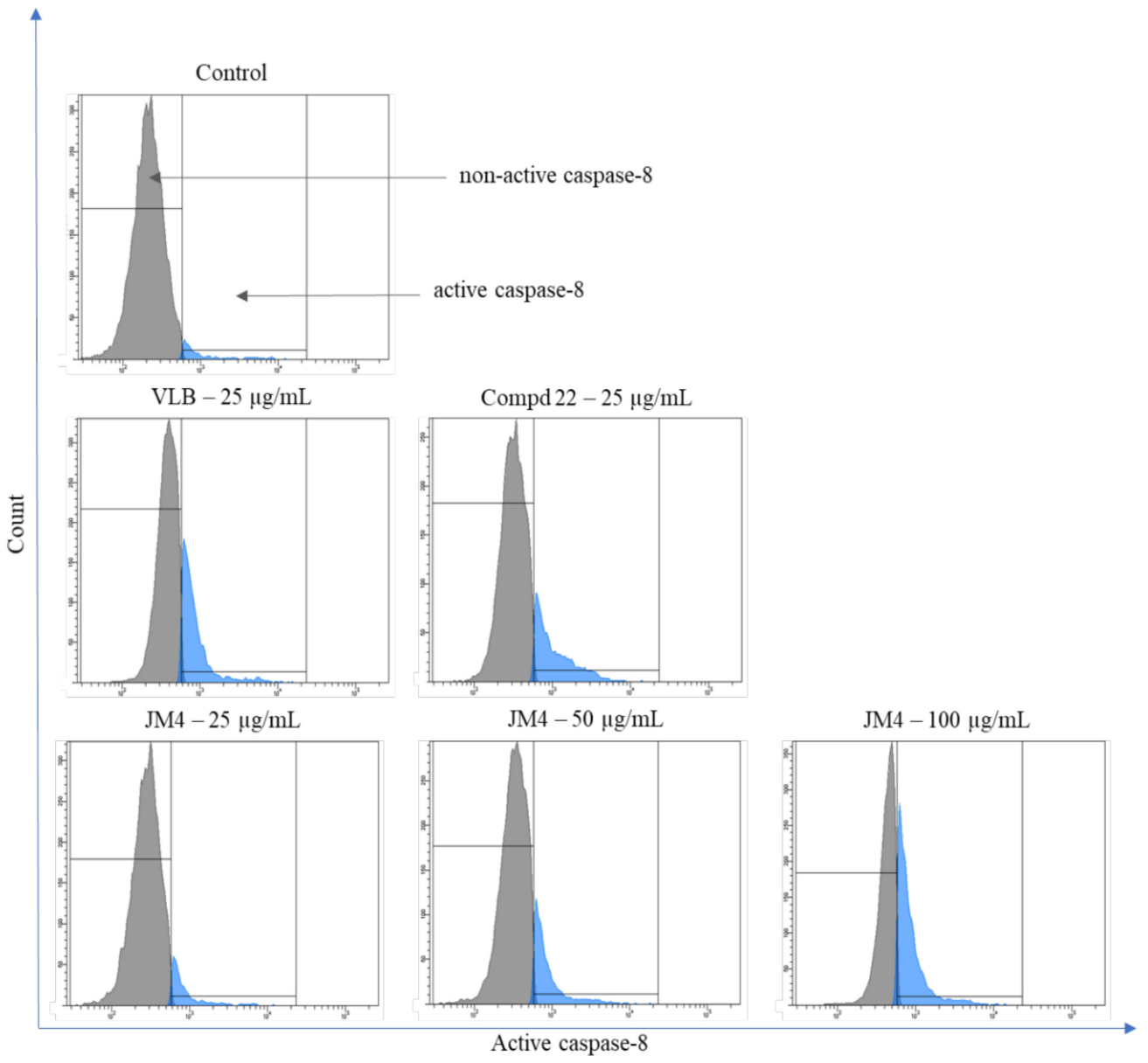

Figure 13. Flow cytometric analysis of populations C32 melanoma cells treated for $24 \mathrm{~h}$ with JM4 (25, 50, $100 \mu \mathrm{g} / \mathrm{mL}), 22$ $(25 \mu \mathrm{g} / \mathrm{mL})$ and vinblastine sulfate (VLB) $(25 \mu \mathrm{g} / \mathrm{mL})$ for active caspase- 8 .

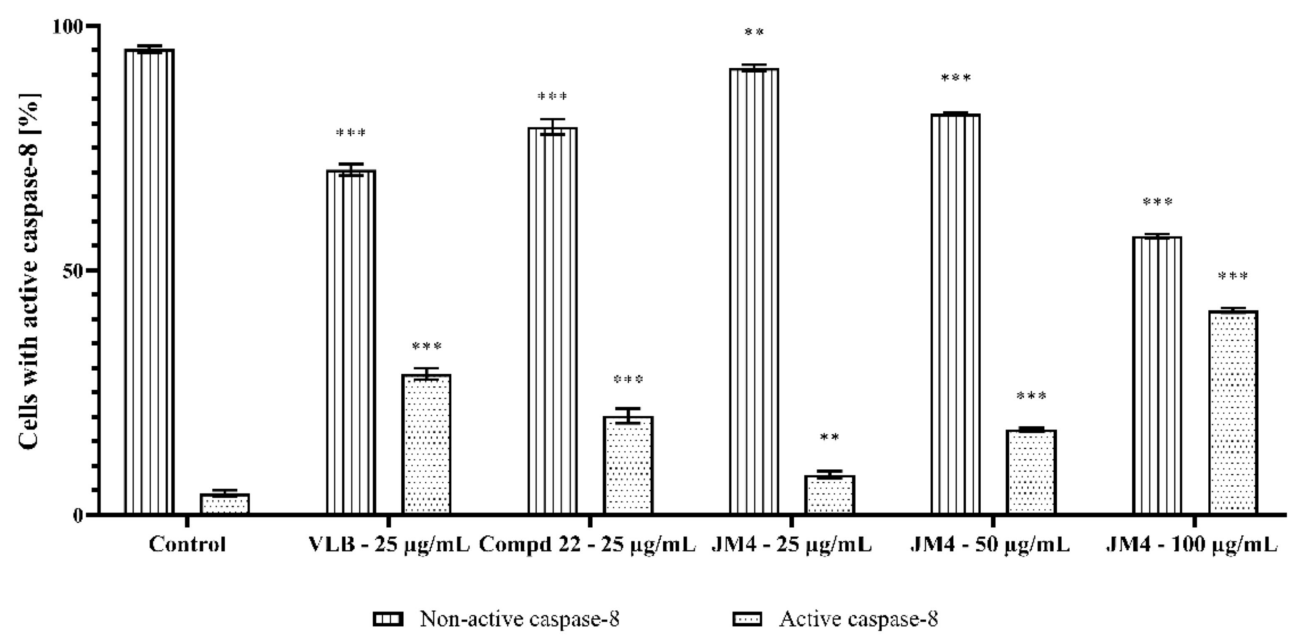

Figure 14. Percentage of C32 melanoma cells with nonactive and active caspase- 8 after 24 h incubation with JM4 (25, 50, $100 \mu \mathrm{g} / \mathrm{mL}), 22(25 \mu \mathrm{g} / \mathrm{mL})$ and vinblastine sulfate (VLB) $(25 \mu \mathrm{g} / \mathrm{mL})$. Mean percentage values from three independent experiments $(n=3)$ done in duplicate are presented. ${ }^{* *} p<0.01$ versus control group, ${ }^{* * *} p<0.001$ versus control group. 


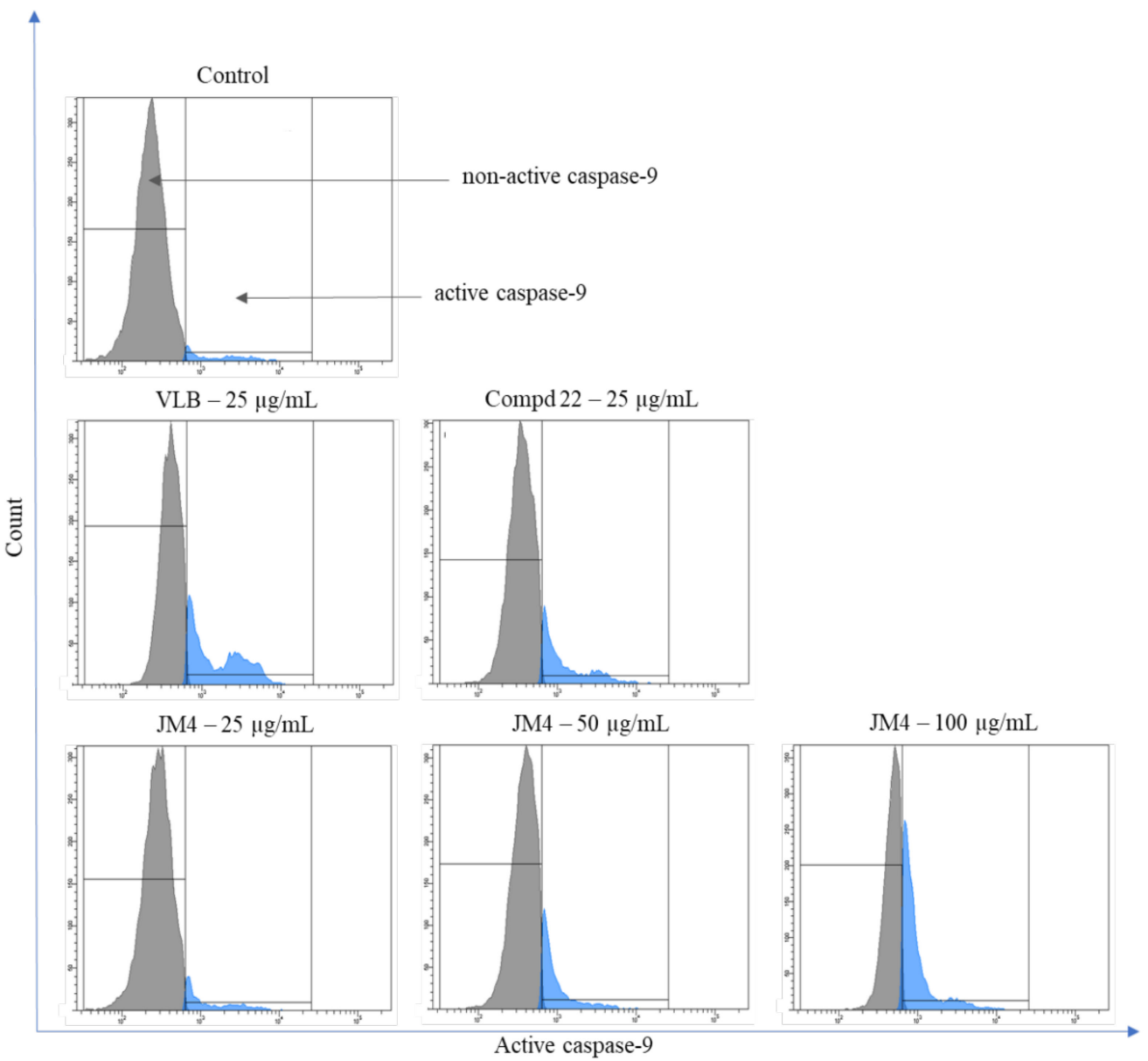

Figure 15. Flow cytometric analysis of populations C32 melanoma cells treated for $24 \mathrm{~h}$ with JM4 $(25,50,100 \mu \mathrm{g} / \mathrm{mL}), 22$ $(25 \mu \mathrm{g} / \mathrm{mL})$ and vinblastine sulfate (VLB) $(25 \mu \mathrm{g} / \mathrm{mL})$ for active caspase- 9 .

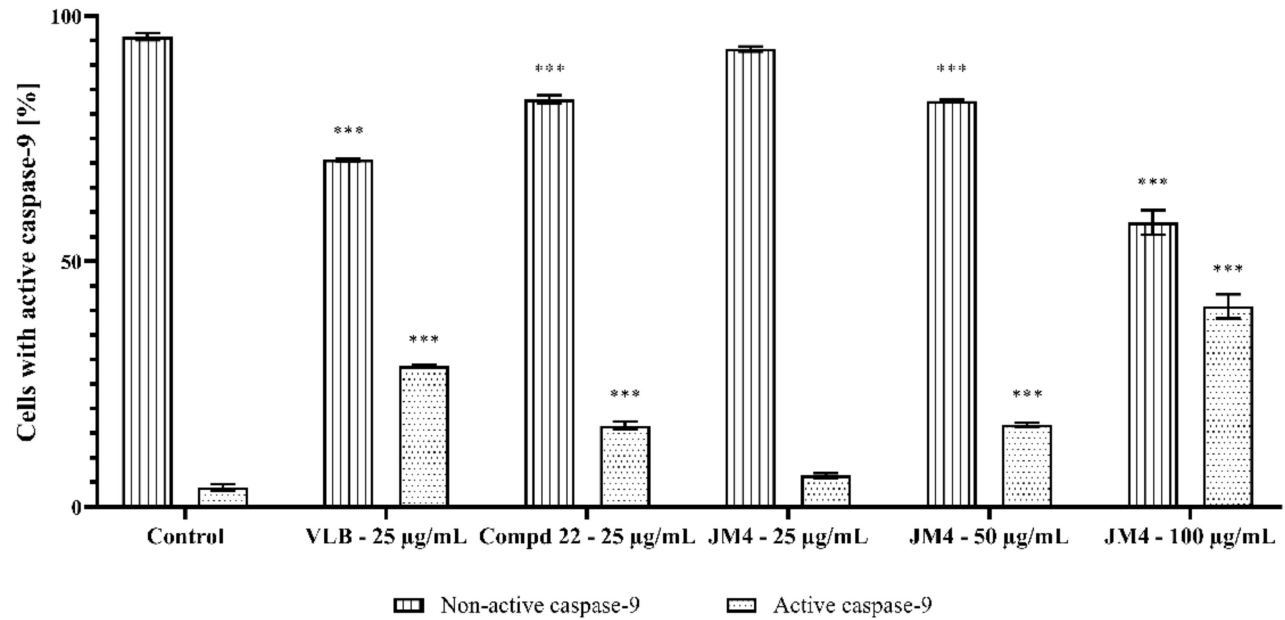

Figure 16. Percentage of C32 melanoma cells with nonactive and active caspase- 9 after 24 h incubation with JM4 (25, 50, $100 \mu \mathrm{g} / \mathrm{mL}), 22(25 \mu \mathrm{g} / \mathrm{mL})$ and vinblastine sulfate (VLB) $(25 \mu \mathrm{g} / \mathrm{mL})$. Mean percentage values from three independent experiments $(n=3)$ done in duplicate are presented. ${ }^{* *} p<0.001$ versus control group. 


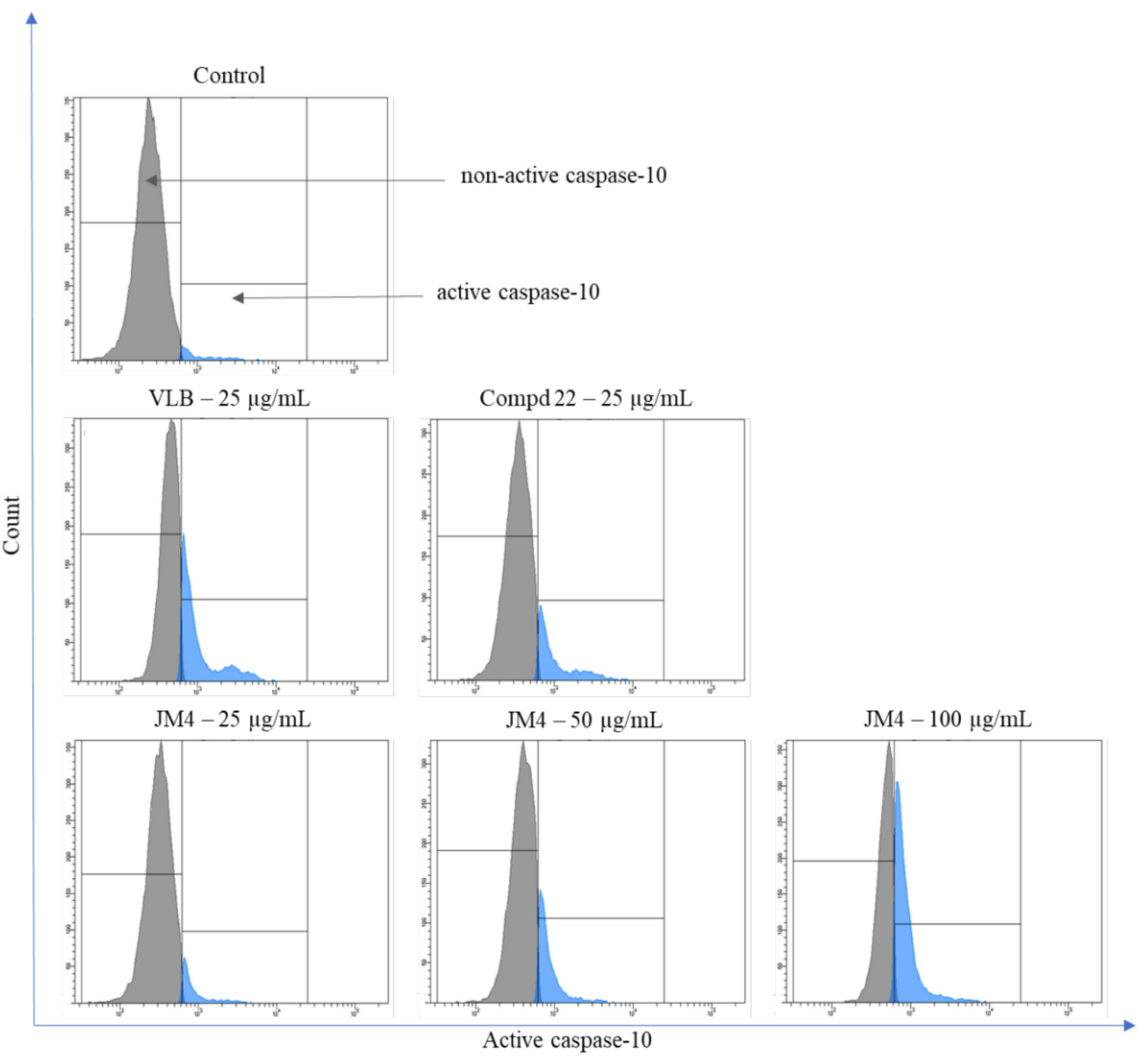

Figure 17. Flow cytometric analysis of populations C32 melanoma cells treated for $24 \mathrm{~h}$ with JM4 (25, 50, $100 \mu \mathrm{g} / \mathrm{mL}), 22$ $(25 \mu \mathrm{g} / \mathrm{mL})$ and vinblastine sulfate (VLB) $(25 \mu \mathrm{g} / \mathrm{mL})$ for active caspase- 10 .

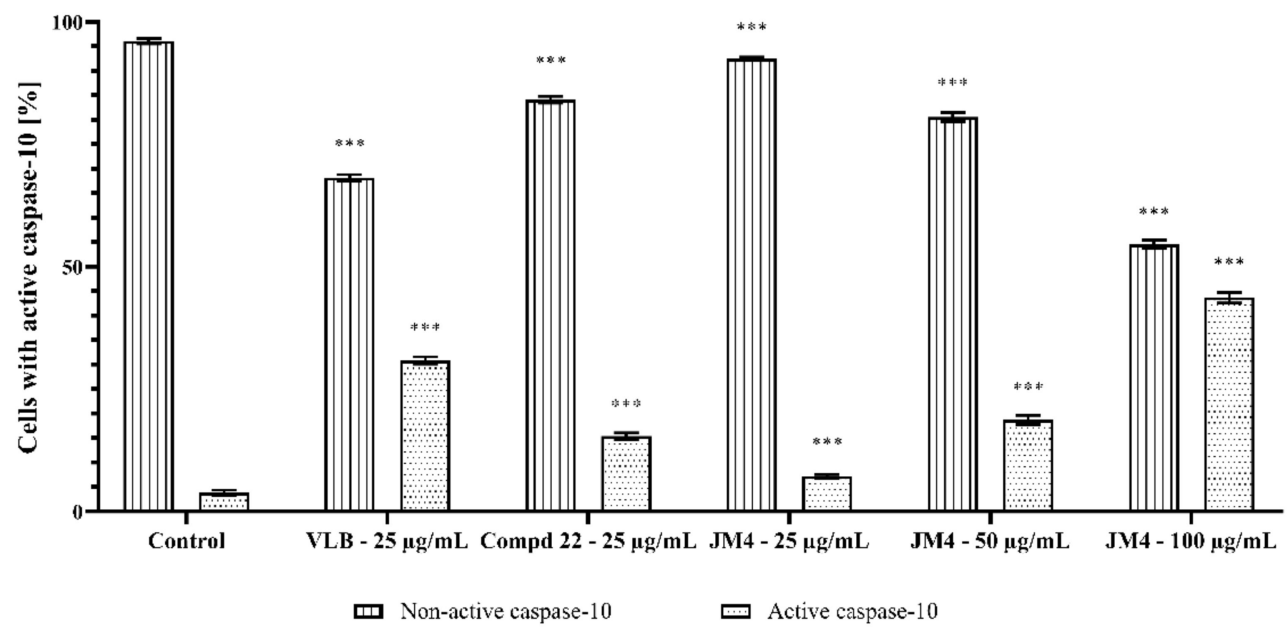

Figure 18. Percentage of C32 melanoma cells with nonactive and active caspase-10 after 24 h incubation with JM4 (25, 50, $100 \mu \mathrm{g} / \mathrm{mL}), 22(25 \mu \mathrm{g} / \mathrm{mL})$ and vinblastine sulfate (VLB) $(25 \mu \mathrm{g} / \mathrm{mL})$. Mean percentage values from three independent experiments $(n=3)$ done in duplicate are presented. ${ }^{* *} p<0.001$ versus control group.

\section{Discussion}

The extracts and fractions obtained from the aerial parts of J. montana were used in this study. Due to the lack of literature data on the phytochemical profile and biological prop- 
erties of J. montana as well as traditional anticancer drugs from J. montana, we performed the isolation and identification of the main compounds from the fractions from J. montana and examined their activity against human amelanotic melanoma C32 cells. Pathological skin cells were selected for this research due to the awareness of problems resulting from unknown plant matrix metabolic pathways when used internally. Additionally, previous studies have suggested the anticancer potential of luteolin and its derivatives [6,31-33]. To the best of our knowledge, there are currently no reports in the literature on the effects of $J$. montana extracts and its main phytoconstituents on C32 cells.

The main phytochemicals belonging to the flavone group that were found and isolated from J. montana herbs include luteolin 7-O-sambubioside, luteolin 7-O-glucoside, and luteolin $(\mathbf{9}, \mathbf{1 2}$, and 22, respectively). During the chromatographic study, it was found that the EtOAc fraction JM4 contained luteolin (22) and luteolin 7-O-glucoside (12). JM5 and the $n$-BuOH fraction JM6 contained luteolin-7-O-sambubioside (9). These compounds were identified by comparison of the obtained UV spectral data as well as ${ }^{1} \mathrm{H}$ and ${ }^{13} \mathrm{C}$ NMR data with the available literature data, thus confirming their presence in the aerial parts of J. montana. The presence of these compounds in the studied species had already been described for the first time [12]. However, compound 9 was isolated for the first time from J. montana.

Luteolin displays numerous health-related properties, such as antiallergy, anti-inflammatory, antioxidant, anticancer activities and it was also reported as MAO-B inhibitors for the treatment of neurodegenerative diseases [34]. In traditional Chinese medicine, plants rich in luteolin have been used for the treatment of various disorders, such as inflammatory diseases, hypertension, and even malignant tumors [7,35]. Luteolin 7-O-glucoside (12) protects cells against apoptosis activated by hypoxia and buffers atopic dermatitis skin lesions in murine models [36].

The metabolic pathways of natural compounds and the complexity of the plant matrix have been insufficiently studied and pose a problem for internal administration. Hence, it seemed appropriate to undertake research towards only the potential external application of the raw material. Many anticancer compounds act by inhibiting tumor growth by arresting the cell cycle and/or inducing apoptosis [37]. The action of luteolin in the context of cancer, including melanoma, has been extensively described in review articles [8,31-33]. There are several suggested mechanisms by which luteolin may exert an inhibitory effect on human melanoma, including the induction of cell cycle arrest [38] or activation of apoptosis by increasing the level of intracellular reactive oxygen species (ROS) [39]. Additionally, the activity of luteolin was evaluated in an experimental in vivo metastasis model of hypoxiainduced epithelial-mesenchymal transition (EMT) inhibition through the regulation of $\beta 3$ integrin [4]. This result was confirmed by luteolin research in melanoma cells, during which attempts were made to determine the influence of luteolin on the programming of the cell cycle, proving the arrest of this process in the G2/M and G0/G1 phases of the cell cycle [3]. Luteolin activates caspase-3, caspase-8, caspase-9, and caspase-10, activates DNA fragmentation factor, reduces MMP, and induces cytochrome $\mathrm{C}$ release into the cytosol [32]. Additionally, research on $\mathrm{CH} 27$ human lung squamous carcinoma cells showed that luteolin causes DNA damage and cell cycle arrest in S phase [40]. The aforementioned anticancer effects and mechanisms of luteolin are only examples of the very broad spectrum of action of this flavonoid [32].

The cytotoxic properties of chemotherapeutic substances are often associated with the induction of apoptosis in cancer cells [41]. Our results demonstrated the cytotoxic potential of the tested samples in amelanotic melanoma C32 cells. These melanoma cells showed a reduction in cell viability in a dose-dependent manner. The calculated $\mathrm{IC}_{50}$ value for all investigated extracts and fractions in the cytotoxic assays allowed us to observe differences in their activity. Luteolin (22) and fraction JM4 showed the greatest cytotoxic potential that was comparable to that of VLB during the next steps of experiment. The presence of 22 in JM4 was confirmed by LC-MS analysis, in which the presence of the ions 269 [M-H] ${ }^{-}$ and $271[\mathrm{M}-\mathrm{H}]^{+}$were found, which corresponded to the mass of the monoisotopic ion of 
luteolin, as well as the LC peak of the standard substance that had the same retention time as luteolin. It is worth noting that the compound 22 was the dominant in the analyzed fraction JM4. However, JM4 was identified as a mixture of other polyphenolic compounds (Supplementary Figure S2).

Said and co-authors set out to determine the antiproliferative potential of flavonoids isolated from Ailanthus excelsa, including $\mathbf{1 2}$ and 22 against the same amelanotic melanoma C32 cell line used in this study as well as large cell lung carcinoma COR-L23 cells and malignant melanoma A375 cells. The results showed that luteolin had strong antiproliferative effects, comparable to those of VLB in all tested cell lines [42]. The observed antiproliferative effects of luteolin indicate that it might play a significant role in the overall activity of JM4.

While both 22 and JM4 displayed notable degrees of cytotoxic activity in C32 cells in this study, their cytotoxic potential against normal fibroblast cells was much lower. To further elucidate the mechanism of cell damage and the possible induction of apoptosis, the ability of the test compounds to arrest the cell cycle was investigated. Flow cytometry analysis showed a decrease in the number of cells in G1 phase, which was most clearly seen in the case of JM4. Additionally, both JM4 and compound 22, at concentrations of 100 and $25 \mu \mathrm{g} / \mathrm{mL}$, respectively, showed an increase in the accumulation of cells in the $\mathrm{S}$ and G2/M phases. Similar results were obtained in A375 melanoma cells. It has been shown that luteolin can contribute to cell cycle arrest and the induction of apoptosis by arresting the cell cycle at the G2/M and G0/G1 phases [3]. Literature data have confirmed that many antitumor substances block the cell cycle in G2/M phase [43-45]. It should be emphasized that there was a significant increase in the number of cells in $S$ phase, which is a significantly higher result than in the case of VLB. The demonstrated disruptions in the cell cycle were associated with the inhibition of cell proliferation.

Apart from cell cycle arrest, mitochondria and caspases play an essential role in the induction of apoptosis. At the cellular level, many factors mediate apoptosis. One is the dysfunction of mitochondrial membrane integrity that can result in apoptotic cell death. Reducing the MMP causes the release of cytochrome $c$ and other proteins. These proteins play an important role in the activation of caspase-9 and hence caspase-3, which directly leads to cell death [46-48]. To show the effects of the mitochondrial pathway on the apoptosis process, flow cytometry analysis was conducted and showed a significant decrease in MMP under the influence of JM4 and compound 22, thus confirming that apoptosis was triggered. Notably, the reduction in MMP in the case of compound 22 was similar to that caused by VLB, and in the case of JM4, it was twice as high as that recorded in the positive control.

The relationship between the reduction in MMP and the induction of the intrinsic apoptotic pathway is based on the activation of pro-caspase-3. In the context of cellular apoptosis, caspase- 8 and caspase-10, which are involved in the external apoptotic pathway, are equally important [49]. As discussed in the results section, JM4 and compound 22 exerted a significant antiproliferative effect in C32 cells that was associated with caspase-8, caspase- 9 , and caspase-10, followed by caspase-3. In a recent paper, Danciu et al. showed that chamomile flower extract presents a proapoptotic effect against human melanoma A375 cells. The dominant components of the studied extract were the following flavonoids: apigenin glucoside, rutin, luteolin glucoside, and luteolin. The chamomile flower extract activated caspase-3 at a concentration of $60 \mu \mathrm{g} / \mathrm{mL}$. However, this flavone complex did not show significant activity in terms of cell cycle distribution or induction of apoptotic phases. This nonsignificant effect of the extract may be caused by the synergistic action of all components of the extract [50]. A similar effect was observed in study on a rosemary extract and human melanoma A375 cells where the extract was subjected to an MTT test with the main pure compounds such as rosmarinic acid, luteolin, carnosol, apigenin, and scutellarin. The dominant compound, rosmarinic acid, showed a much weaker antiproliferative effect than the extract. The substances whose contents in the extract were lower (carnosol, apigenin and luteolin) turned out to be more effective. However, since the individual 
substances were effective at concentrations well above those found in the rosemary extract, the results suggested that the cytotoxicity of the whole extract was due to the combination of activities of different substances [51].

Autophagy may have two functions: protumorigenic and antitumorigenic, depending on the type of cell, stage of cancer development and stimulator [24]. Most of the currently available chemotherapeutic agents exert their cytotoxic activity by promoting apoptosis. Previous reports have indicated that autophagy is essential in cancer therapy as well as apoptosis [52-55]. These assumptions are supported by studies on the effects of another natural polyphenol, curcumin, in melanoma A375 cells. Zhao et al. proved the relationship between the induction of cell proliferation and autophagy [56]. Our results led to similar conclusions by showing the activation of autophagy and apoptosis under the influence of JM4 and compound 22.

Thus, the induction of apoptosis in cancer cells treated with fraction JM4 described in this study may be partly explained by the presence of luteolin (22). However, the conducted studies, which were aimed at demonstrating the induction of apoptosis in neoplastic cells under the influence of the tested fraction and pure compound, showed differences in the mitochondrial potential, caspase activation and the number of cells in the apoptotic phases between the samples used. This may be because the plant matrix of the fraction JM4 is present and because of the possible synergism of the various phytochemical components such as compound 22 and its derivatives. Previous studies on luteolin (22) and its antitumor effects have confirmed its inhibitory effect against various types of cancer, including human lung carcinoma cells [40], oral squamous cancer cells [57], human esophageal adenocarcinoma cells [58], human colon cancer cells [59], human hepatoma cells [60], breast cancer, pancreatic cancer, prostate cancer, glioblastoma, and many others [7]. Hence, it is possible to hypothesize that J. montana, as a rich source of derivatives of luteolin, may be the basis for further research due to their potential antitumor activity.

\section{Materials and Methods}

\subsection{Chemicals and Reagents}

Methanol (MeOH) (CAS67-56-1), petroleum spirit (CAS8032-32-4), chloroform $\left(\mathrm{CHCl}_{3}\right)$ (CAS67-66-3), diethyl ether ( $\mathrm{Et}_{2} \mathrm{O}$ ) (CAS60-29-7), ethyl acetate (EtOAc) (CAS141-78-6), $n$-butanol (n-BuOH) (CAS71-36-3), ethanol (EtOH) (CAS64-17-5), Sephadex LH-20, vinblastine sulfate (VLB) (CAS143-67-9), dimethyl sulfoxide (DMSO) (CAS67-68-5), and 3-(4,5dimethylthiazol-2-yl)-2,5-diphenyl tetrazolium bromide (MTT) (CAS298-93-1) obtained from Sigma Aldrich Co. (St. Louis, MO, USA). Polyamide (CAS25038-54-4), chrysoeriol and $p$-coumaric acid were purchased from Carl ROTH (Karlsruhe, Germany). The human amelanotic melanoma cell line C32 (CRL-1585) and a normal human fibroblast cell line (PCS-201-012) were purchased from the American Type Culture Collection (ATCC; Manassas, VA, USA). Dulbecco's minimal essential medium (DMEM), fetal bovine serum (FBS), phosphate-buffered saline (PBS), glutamine, penicillin, and streptomycin were purchased from Corning (Corning, NY, USA). Propidium iodide (PI) (CAS 25535-16-4), stain buffer, and an FITC Annexin V Apoptosis Detection Kit II were obtained from BD Pharmingen (San Diego, CA, USA). Fixable Viability Stain 520 (FVS520) was from BD Horizon, San Diego, CA, USA and the DNase-free RNase A Solution was acquired from Promega, Madison, WI, USA. The Autophagy Assay, Red kit, FLICA Caspase-3/7 Assay Kit, FLICA Caspase-8 Assay Kit, FLICA Caspase-9 Assay Kit, and FLICA Caspase-10 Assay Kit were purchased from ImmunoChemistry Technologies (Bloomington, MN, USA). The JC-1 MitoScreen kit was from BD Biosciences Systems (San Jose, CA, USA). Ultra-pure water (UPW) for the preparation of the mobile phase for LC-PDA-ESI-MS/TOF analysis was performed on a POLWATER DL3-100 system (Labopol, Kraków, Poland). Acetonitrile (MeCN) (CAS75-0508) was purchased from Fisher Chemical (Thermo Fisher Scientific, Leicestershire, UK), and both mobile phases were modified with the addition of formic acid (HCOOH) (CAS64-18-6) (Ph. Eur., Merck, Darmstadt, Germany). Apigenin (purity > 96\%) and tricin (purity $>96 \%$ ) were isolated from the inflorescences of Arctium tomentosum [61] and Cirsium palustre flower 
heads [62], respectively. Luteolin 7-O-sambubioside, luteolin 7-O-glucoside, and luteolin were isolated from J. montana as described below.

\subsection{Plant Material}

The aboveground parts of $J$. montana $(2.0 \mathrm{~kg})$ were collected from plants occurring in their natural habitat within the area of Puszcza Knyszyńska (N53 ${ }^{\circ} 5^{\prime} 20.9^{\prime \prime} ;$ E23 $\left.25^{\prime} 41.5^{\prime \prime}\right)$ in the region of Supraśl (Podlasie Province, Poland) within the period of June-August 2017 and 2018. The plant material was dried in a shaded and well-ventilated area. Samples of the collected plant material were identified based on the scientific botanical literature and its morphological features by one of the authors (M.T.). A plant voucher specimen (JM-15029) has been deposited in the Herbarium of the Department of Pharmacognosy at the Medical University of Białystok, Poland.

\subsection{Preparation of Extracts JM1-JM3 and Fractions JM4-JM6}

The raw plant material ( $5 \mathrm{~g}$ per sample) was powdered and subsequently extracted using a heating mantle and radiator $(5 \times 45 \mathrm{~min})$. All extractions were carried out using $65 \mathrm{~mL}$ of one of the following solvents: $\mathrm{H}_{2} \mathrm{O}$ (JM1), $50 \% \mathrm{MeOH}$ (JM2), and $\mathrm{MeOH}$ (JM3). After filtration of the extracts, the solvents were evaporated under reduced pressure (BÜCHI System, Flawil, Switzerland) at a controlled temperature of $40 \pm 2{ }^{\circ} \mathrm{C}$. The remaining residues were suspended in water and lyophilized using a freeze-drier (Lyph-Lock, Labonco, Italy). The following amounts of the extracts were obtained: JM1, $1293 \mathrm{mg}$; JM2, $1238 \mathrm{mg}$; and JM3, $858 \mathrm{mg}$. Additionally, the plant material $(130 \mathrm{~g})$ was purified with a continuous extraction method using extraction petrol $(1.5 \mathrm{~L} \times 8 \mathrm{~h})$, and then $\mathrm{CHCl}_{3}$ $(1.5 \mathrm{~L} \times 8 \mathrm{~h})$ in Soxhlet extractor. The purified raw material was exhaustively extracted with $\mathrm{MeOH}(20 \times 3 \mathrm{~L})$ and $50 \%(v / v) \mathrm{MeOH}(3 \mathrm{~L})$ for 45 min each time. After the obtained $\mathrm{MeOH}$ extracts were combined and evaporated to dryness, they were precipitated with water for elimination of the ballasts. The obtained water extract was exhaustively fractionated by liquid-liquid extraction with different solvents of increasing polarity: $\mathrm{CHCl}_{3}$ $(35 \times 200 \mathrm{~mL}), \mathrm{Et}_{2} \mathrm{O}(\mathrm{JM} 4 ; 50 \times 200 \mathrm{~mL}), \mathrm{EtOAc}(\mathrm{JM} 5 ; 98 \times 200 \mathrm{~mL})$ and $n-\mathrm{BuOH}(\mathrm{JM} 6$; $45 \times 200 \mathrm{~mL}$ ). All fractions were evaporated to dryness and finally lyophilized using a freeze-drier. The three fractions were obtained in the following amounts: JM4, $8.5 \mathrm{~g}$; JM5, $29 \mathrm{~g}$; and JM6, $38.5 \mathrm{~g}$ and were used for further experiments. The chloroform fraction $\left(\mathrm{CHCl}_{3}\right)$ was not investigated.

\subsection{LC-ESI-MS Analysis of Extracts JM1-JM3 and Fractions JM4-JM6}

To establish the phytochemical compositions of JM1-JM6, LC-PDA-ESI-MS/TOF analysis was performed on a 1260 Infinity chromatography system hyphenated to a 6230 TOF mass spectrometer and Dual Agilent Jet Stream ESI (Agilent Technologies, Santa Clara, CA, USA). The MS conditions were as follows: electrospray ionization (ESI) source in both positive and negative ionization mode, a gas flow of $12 \mathrm{~L} / \mathrm{min}$, a gas temperature of $325^{\circ} \mathrm{C}$, a nebulizer pressure of $45 \mathrm{psi}$, and capillary voltages of 4500 and $2500 \mathrm{~V}$ for positive and negative ion modes, respectively. The analysis was performed using a Kinetex XB-C18 column $(150 \times 2.1 \mathrm{~mm}, 1.7 \mu \mathrm{m}$; Phenomenex, Torrance, CA, USA). The mobile phases were UPW (solvent A) and $\mathrm{MeCN}$ (solvent $\mathrm{B}$ ), both with $0.1 \% \mathrm{HCOOH}$. The gradient started with the elution of $5 \%$ solvent B over $1.5 \mathrm{~min}$. Then, within $22 \mathrm{~min}$, the concentration of solvent $\mathrm{B}$ reached $28 \%$, in $35 \mathrm{~min}$ it reached $75 \%$, and finally in $45 \mathrm{~min}$ it reached $95 \%$, with a linear gradient. After 3 min of maintaining the $95 \%$ B concentration, in $49 \mathrm{~min}$, the system returned to its initial conditions, and conditioning continued for $6 \mathrm{~min}$. The total run time of the analysis was $55 \mathrm{~min}$ at $25^{\circ} \mathrm{C}$. The injection volume was $1.0 \mu \mathrm{L}$, and the flow rate was $0.1 \mathrm{~mL} / \mathrm{min}$.

\subsection{Identification and Isolation of Main Compounds $\mathbf{9}, \mathbf{1 2}$ and 22 (JM7-JM9)}

Fractions JM4-JM6 underwent labor-intensive isolation procedures with low pressure liquid chromatography (LPLC) to isolate the active compounds using various ad- 
sorbents, such as polyamide and Sephadex LH-2. The fractionation process was controlled by thin layer chromatography (TLC) (TLC Cellulose, $20 \times 20 \mathrm{~cm}$, MERCK, $n$ $\mathrm{BuOH}: \mathrm{CH}_{3} \mathrm{COOH}: \mathrm{H}_{2} \mathrm{O}, 4: 1: 5(v / v / v)$; upper layer, sprayed with $1 \%$ Naturstoff reagent A) analysis under UV light. Isolated, chromatographically homogeneous compounds 9 (250 mg), 12 (1640 mg), and $22(139 \mathrm{mg}$ ) were subjected to spectral analyses to determine their full structural characteristics. Spectral measurements were performed using UV-VIS (SPECORD 200 Plus, Analytik Jena, Jena, Germany) with various complexing reagents and ${ }^{1} \mathrm{H}$ NMR and ${ }^{13} \mathrm{C}$ NMR spectra were recorded (BRUKER Advance II 400, BRUKER, Billerica, MA, USA). The final characteristics of all isolated compounds were also confirmed by MS (Agilent, Santa Clara, CA, USA).

\subsection{Biological Assays \\ 4.6.1. Cell Culture}

The human amelanotic melanoma cell line C32 (CRL-1585) and a normal human fibroblast cell line (PCS-201-012) were cultured in DMEM. DMEM was blended with 10\% FBS, $10 \mu \mathrm{g} / \mathrm{mL}$ streptomycin, and 10 units $/ \mathrm{mol}$ penicillin. The cells were cultured in $5 \%$ $\mathrm{CO}_{2}$ and fully humidified at $37^{\circ} \mathrm{C}$. All tested compounds were used at a final DMSO concentration of not more than $0.5 \%(v / v)$. Cells cultured in drug-free DMEM were used as controls, and cells with the addition of only DMSO were used as solvent-controls; VLB was used as a positive control. The JM4 fraction was analyzed at the following concentrations: 25,50 and $100 \mu \mathrm{g} / \mathrm{mL}$ and compound 22 and VLB were analyzed at $25 \mu \mathrm{g} / \mathrm{mL}$. For the cytotoxicity assay, all extracts and compounds were tested at the following concentrations: $10,25,50,100,200$, and $300 \mu \mathrm{g} / \mathrm{mL}$.

\subsubsection{Cytotoxicity Assay}

Cytotoxicity was evaluated by the MTT colorimetric assay previously described by Carmichael [63]. The MTT test is founded on the reduction of a yellow tetrazolium salt to purple formazan crystals by viable cells. C32 and fibroblast cells were seeded in 24-well plates at an initial density of $1 \times 105$ cells per well. The cultured cells were grown at $37{ }^{\circ} \mathrm{C}$ for $24 \mathrm{~h}$ and incubated with JM1-JM6 and compounds 9, 12 and 22 at various concentrations for $24 \mathrm{~h}$. Each sample was dissolved in DMSO (the DMSO concentration was no greater than $0.5 \%$ ) and further diluted in serum-free DMEM to achieve different concentrations (10-300 $\mu \mathrm{g} / \mathrm{mL})$. After incubation, $10 \mu \mathrm{L}$ of MTT solution $(5 \mathrm{mg} / \mathrm{mL}$ ) was added to all cultured cells and followed by an additional incubation for $4 \mathrm{~h}$ (fibroblast cell line) or $10 \mathrm{~min}$ (C32 cell line). Upon removal of the medium, $200 \mu \mathrm{L}$ of DMSO was added to all wells to dissolve the insoluble formazan. The results were measured spectrophotometrically at $570 \mathrm{~nm}$ using an Evolution 201 reader (Thermo Scientific, Waltham, MA, USA).

\subsubsection{Fixable Viability Stain Assay}

This analysis was performed to estimate the level of viable cells after treatment with JM1-JM6, compounds 9, 12, 22 and VLB at concentrations ranging from 10 to $300 \mu \mathrm{g} / \mathrm{mL}$. Cytotoxicity was evaluated by FVS520 via a flow cytometer (BD FACSCanto II flow cytometer, San Jose, CA, USA). In contrast to nonpermeable live cells, the permeable membranes of necrotic cells allow for the intracellular diffusion of FVS520 and the covalent binding of high concentrations of amines. Thus, necrotic cells contained a higher level of FVS520 and, consequently, increased fluorescence intensity than viable cells. After $24 \mathrm{~h}$ of incubation, C32 cells and fibroblasts were washed with PBS, trypsinized and resuspended in DMEM. The supernatant was removed, and $0.5 \mathrm{~mL}$ of Stain Buffer with the addition of 1 $\mu \mathrm{L}$ of FVS520 was added to each sample, which was vortexed immediately and kept for $10-15 \mathrm{~min}$ in the dark at room temperature. After incubation and the addition of $2 \mathrm{~mL}$ of PBS, the supernatant was removed, the cells were resuspended in $300 \mu \mathrm{L}$ of PBS and then immediately subjected to analysis. The results were analyzed based on FACSDiva software (BD Biosciences Systems, San Jose, CA, USA). Based on the results of the cytotoxicity 
analysis, further research in this project focused on the determination of the full anticancer mechanism of the most promising fraction JM4 and compound 22.

\subsubsection{Cell Cycle Analysis}

The allocation of cell cycle stage was analyzed on a FACSCanto II flow cytometer. C32 cells were cured with JM4, 22 and VLB for $24 \mathrm{~h}$ of incubation. Thereafter, the cells were harvested and adjusted with $1 \mathrm{~mL}$ of $70 \% \mathrm{EtOH}$ and maintained at $-20^{\circ} \mathrm{C}$ for $24 \mathrm{~h}$. Next, the cells were washed with PBS, treated with $50 \mu \mathrm{g} / \mathrm{mL}$ DNase-free RNase A solution for $5 \mathrm{~min}$ at room temperature, stained with $100 \mu \mathrm{g} / \mathrm{mL}$ PI for $30 \mathrm{~min}$ at $37^{\circ} \mathrm{C}$, and submitted to flow cytometry analysis. The results were analyzed with FACSDiva software.

\subsubsection{Flow Cytometry Assessment of Annexin V Binding}

Characterization of the mode of apoptosis induced by JM4, 22 and VLB was performed in C32 cells via flow cytometry using a FITC Annexin V Apoptosis Detection Kit II. All stages of programmed cell death could be identified by annexin $V$ bound with high affinity to PS. PI is a standard flow cytometric viability explorer that stains cells that interfere with the cell membrane, and it can be used to distinguish necrotic cells from dead cells. After the C32 cells were incubated for $24 \mathrm{~h}$ with various concentrations of JM4, 22 and VLB, they were trypsinized and resuspended in binding buffer. After that, $5 \mu \mathrm{L}$ of annexin V-FITC and $5 \mu \mathrm{L}$ of PI were added and maintained for $15 \mathrm{~min}$ in the dark at room temperature. The results were analyzed using FACSDiva software.

\subsubsection{Determination of the Level of Autophagy by Autophagy Assay, Red}

An autophagy assay was carried out to detect the impact of JM4, compound 22, and VLB on the autophagy process of C32 cells via flow cytometry using an Autophagy Assay, Red kit. The probe is a cell-permeable aliphatic molecule that brightly fluoresces after unjumbling autophosphates and autolysosomes into lipid membranes. Samples of C32 cells incubated for $24 \mathrm{~h}$ with JM4, 22, and VLB were subjected to a rising procedure with PBS and then resuspended in PBS with the accessory of Autophagy Probe, Red solution, and maintained for $30 \mathrm{~min}$ at $37^{\circ} \mathrm{C}$ in the dark. After incubation, the cells were flushed again and resuspended in cellular assay buffer. The results were analyzed with FACSDiva software.

\subsubsection{Analysis of Mitochondrial Membrane Potential (MMP)}

Disorder of the MMP was determined by the lipophilic cationic probe 5,5',6,6'-tetrachloro1,1',3,3'-tetrarthylbenzimidazol-carbocyanine iodide using a JC-1 MitoScreen kit. Samples of C32 cells after the $24 \mathrm{~h}$ incubation with JM4, compound 22, and VLB, were subjected to a rising procedure with PBS, suspended in PBS with $10 \mu \mathrm{g} / \mathrm{mL} \mathrm{JC}-1$ and maintained for $15 \mathrm{~min}$ at room temperature in the dark. After incubation, the cells were flushed again, resuspended in PBS, and immediately subjected to BD FACSCanto II flow cytometry analysis. The results were analyzed using FACSDiva.

\subsubsection{Determination of Caspase-3, Caspase-8, Caspase-9, and Caspase-10 Activity}

Determination of the caspase-3, caspase- 8 , caspase-9, and caspase-10 activity were carried out by the following kits: FLICA Caspase-3/7 Assay Kit, FLICA Caspase-8 Assay Kit, FLICA Caspase-9 Assay Kit, and FLICA Caspase-10 Assay Kit using a BD FACSCanto II flow cytometer. C32 cells were incubated with JM4, compound 22 and VLB for $24 \mathrm{~h}$, washed twice with PBS, resuspended in buffer supplemented with $5 \mathrm{~mL}$ of FLICA reagent, and incubated. After $1 \mathrm{~h}$, the cells were flushed with apoptosis wash buffer and resuspended in $100 \mathrm{~mL}$ of the same reagent with $10 \mathrm{mg} / \mathrm{mL}$ PI. The procedure of determining the activity of each caspase was carried out analogously. The results were analyzed with FACSDiva software.

\subsubsection{Cell Morphological Analysis}

Visualization of the nuclear morphology of C32 cells was evaluated using a phase contrast microscope (Nikon Eclipse Ti, Tokyo, Japan) at 200× magnification. C32 cells 
$\left(2.5 \times 10^{5}\right)$ were incubated with $\mathbf{J M} 4$ at concentrations of 25,50 , and $100 \mu \mathrm{g} / \mathrm{mL}$ and compound 22 and VLB at a concentration of $25 \mu \mathrm{g} / \mathrm{mL}$ in 6-well plates for $24 \mathrm{~h}$ at $37^{\circ} \mathrm{C}$. After incubation, the cells were washed twice with PBS and observed under a phase contrast microscope.

\subsubsection{Statistical Analysis}

All numerical data are shown as the mean \pm standard deviation (SD) from at least three independent repeats. Statistical analysis was performed using GraphPad Prisma 8 software (GraphPad Software, San Diego, CA, USA). Statistical differences were assessed using one-way ANOVA followed by Tukey's test. Values of $p<0.05$ were considered statistically significant.

\section{Conclusions}

Summarizing, the results of conducted studies indicate that J. montana is a rich source of polyphenolic compounds, mainly luteolin and its derivatives demonstrated significant cytotoxic and proapoptotic potential. The obtained results have shown that J. montana may be an effective strategy to develop preparation with potential antimelanoma properties. However, further studies are required in the human system to determine cellular uptake, distribution, and the long-term effect of the isolated flavonoids in the skin.

Supplementary Materials: The following are available online at https:/ / www.mdpi.com/1422-006 7/22/7/3345/s1, Figure S1: The qualitative assessment of J. montana extracts (JM1-JM3). UV-VIS chromatogram $(\lambda=280 \mathrm{~nm})$ obtained by LC-PDA-MS, Figure S2: The qualitative assessment of J. montana fractions (JM4-JM6). UV-VIS chromatogram $(\lambda=280 \mathrm{~nm})$ obtained by LC-PDA-MS, Figure S3: 1H NMR spectrum (400.15 MHz, DMSO-d6) of compound 9, Figure S4: 13C NMR spectrum (400.15 MHz, DMSO-d6) of compound 9, Figure S5: The MS spectrum of compound 9 in positive ion mode, Figure S6: 1H NMR spectrum (400.15 MHz, DMSO-d6) of compound 12, Figure S7: 13C NMR spectrum (400.15 MHz, DMSO-d6) of compound 12, Figure S8: $1 \mathrm{H}$ NMR spectrum (400.3 MHz, DMSO-d6) of compound 22, Figure S9: Flow cytometric analysis of cytotoxicity of C32 melanoma cells after $24 \mathrm{~h}$ of incubation with DMSO and $\operatorname{VLB}(10,25,50,100,200$, and $300 \mu \mathrm{g} / \mathrm{mL})$ comparable with untreated control by the fixable viability stain assay, Figure S10: Flow cytometric analysis of cytotoxicity of C32 melanoma cells after 24 h of incubation with JM1-JM3 (10, 25, 50, 100, 200, and $300 \mu \mathrm{g} / \mathrm{mL}$ ) comparable with untreated control by the fixable viability stain assay, Figure S11: Flow cytometric analysis of cytotoxicity of C32 melanoma cells after $24 \mathrm{~h}$ of incubation with JM4-JM6 (10, $25,50,100,200$, and $300 \mu \mathrm{g} / \mathrm{mL}$ ) comparable with untreated control by the fixable viability stain assay, Figure S12: Flow cytometric analysis of cytotoxicity of C32 melanoma cells after $24 \mathrm{~h}$ of incubation with compound 9, 12, and $22(10,25,50,100,200$, and $300 \mu \mathrm{g} / \mathrm{mL})$ comparable with untreated control by the fixable viability stain assay, Figure S13: Flow cytometric analysis of cytotoxicity of normal human fibroblasts cells after $24 \mathrm{~h}$ of incubation with DMSO, JM4, and compound 22 (10, 25, 50, 100, 200 , and $300 \mu \mathrm{g} / \mathrm{mL}$ ) comparable with untreated control by the fixable viability stain assay.

Author Contributions: Conceptualization, A.M.J. and M.T.; methodology, A.M.J., R.C., J.W.S. and M.Z.K.; formal analysis, K.B. and M.T.; investigation, A.M.J., R.C., J.W.S. and M.Z.K.; writingoriginal draft preparation, A.M.J., R.C., J.W.S., M.Z.K. and M.T.; writing-review and editing, K.B. and M.T.; visualization, A.M.J.; supervision, M.T.; project administration, A.M.J. and M.T. All authors have read and agreed to the published version of the manuscript.

Funding: The work was funded by the project № POWR.03.02.00-00-I051/16 from European Union funds, POWER 2014-2020, grant No. 05/IMSD/G/2019.

Institutional Review Board Statement: Not applicable.

Informed Consent Statement: Not applicable.

Conflicts of Interest: The authors declare no conflict of interest. 


\begin{tabular}{|c|c|}
\hline $\mathrm{CHCl}_{3}$ & chloroform \\
\hline CMM & cutaneous malignant melanoma \\
\hline DMEM & Dulbecco's minimal essential medium \\
\hline DMSO & dimethyl sulfoxide \\
\hline ESI & electrospray ionization \\
\hline $\mathrm{Et}_{2} \mathrm{O}$ & diethyl ether \\
\hline EtOAc & ethyl acetate \\
\hline $\mathrm{EtOH}$ & ethanol \\
\hline FBS & fetal bovine serum \\
\hline $\mathrm{HCOOH}$ & formic acid \\
\hline $\mathrm{H}_{2} \mathrm{O}$ & water \\
\hline $\mathrm{IC}_{50}$ & median inhibitory concentration \\
\hline LPLC & low pressure liquid chromatography \\
\hline LC-PDA-ESI-MS/TOF & $\begin{array}{l}\text { liquid chromatography-photodiode array detection-electrospray } \\
\text { ionization-mass spectrometry }\end{array}$ \\
\hline $\mathrm{MeCN}$ & acetonitrile \\
\hline $\mathrm{MeOH}$ & methanol \\
\hline MMP & mitochondrial membrane potential \\
\hline MS & mass spectrometer \\
\hline NMR & nuclear magnetic resonance \\
\hline MTT & 3-(4,5-dimethylthiazol-2-yl)-2,5-diphenyl tetrazolium bromide \\
\hline$n-\mathrm{BuOH}$ & $n$-butanol \\
\hline PBS & phosphate-buffered saline \\
\hline PDA & photodiode array detection \\
\hline PI & propidium iodide \\
\hline PS & phosphatidylserine \\
\hline ROS & reactive oxygen species \\
\hline TLC & thin layer chromatography \\
\hline UPW & ultra-pure water \\
\hline UV & ultraviolet \\
\hline UV-VIS & ultraviolet-visible spectroscopy \\
\hline WHO & World Health Organization \\
\hline VLB & vinblastine sulfate \\
\hline
\end{tabular}

\section{References}

1. World Health Organization. Radiation: Ultraviolet (UV) Radiation and Skin Cancer. Available online: https://www.who.int/ news-room/q-a-detail/radiation-ultraviolet-(uv)-radiation-and-skin-cancer (accessed on 28 January 2020).

2. Majumder, D.; Debnath, M.; Libin Kumar, K.V.; Nath, P.; Debnath, R.; Sarkar, C.; Prasad, G.B.K.S.; Verma, Y.K.; Maiti, D. Metabolic profiling and investigations on crude extract of Olea europaea L. leaves as a potential therapeutic agent against skin cancer. J. Funct. Foods 2019, 58, 266-274. [CrossRef]

3. George, V.C.; Kumar, D.R.N.; Suresh, P.K.; Kumar, S.; Kumar, R.A. Comparative studies to evaluate relative In Vitro potency of luteolin in inducing cell cycle arrest and apoptosis in HaCat and A375 cells. Asian Pac. J. Cancer Prev. 2013, 14, 631-637. [CrossRef] [PubMed]

4. Ruan, J.S.; Liu, Y.P.; Zhang, L.; Yan, L.G.; Fan, F.T.; Shen, C.S.; Wang, A.Y.; Zheng, S.Z.; Wang, S.M.; Lu, Y. Luteolin reduces the invasive potential of malignant melanoma cells by targeting $\beta 3$ integrin and the epithelial-mesenchymal transition. Acta Pharmacol. Sin. 2012, 33, 1325-1331. [CrossRef]

5. Davis, L.E.; Shalin, S.C.; Tackett, A.J. Current state of melanoma diagnosis and treatment. Cancer Biol. Ther. 2019, 20, 1366-1379. [CrossRef]

6. Momtaz, S.; Niaz, K.; Maqbool, F.; Abdollahi, M.; Rastrelli, L.; Nabavi, S.M. STAT3 targeting by polyphenols: Novel therapeutic strategy for melanoma. BioFactors 2017, 43, 347-370. [CrossRef] [PubMed]

7. Imran, M.; Rauf, A.; Abu-Izneid, T.; Nadeem, M.; Shariati, M.A.; Khan, I.A.; Imran, A.; Orhan, I.E.; Rizwan, M.; Atif, M.; et al. Luteolin, a flavonoid, as an anticancer agent: A review. Biomed. Pharmacother. 2019, 112, 108612. [CrossRef]

8. Oliveira Júnior, R.; Ferraz, C.; Silva, M.; Lavor, É.; Rolim, L.; Lima, J.; Fleury, A.; Picot, L.; Quintans, J.; Quintans-Júnior, L.; et al. Flavonoids: Promising natural products for treatment of skin cancer (melanoma). In Natural Products and Cancer Drug Discovery; Badria, F.A., Ed.; IntechOpen: London, UK, 2017; pp. 161-2010. ISBN 978-953-51-3313-1. 
9. Lelli, D.; Pedone, C.; Sahebkar, A. Curcumin and treatment of melanoma: The potential role of microRNAs. Biomed. Pharmacother. 2017, 88, 832-834. [CrossRef]

10. Yi, C.; Li, X.; Chen, S.; Liu, M.; Lu, W.; Ye, X. Natural product corynoline suppresses melanoma cell growth through inducing oxidative stress. Phyther. Res. 2020, 34, 2766-2777. [CrossRef]

11. Parnell, J.A.N. Biological flora of the British Isles. Jasione montana L. J. Ecol. 1985, 73, 341-358. [CrossRef]

12. Zapesochnaya, G.G.; Nikolaeva, V.G.; Ban'kovskii, A.I. The flavonoids of Jasione montana and Melittis sarmatika. Chem. Nat. Compd. 1972, 8, 112. [CrossRef]

13. Trojanowska, A. Traditional Belarussian herbal medicine in paper Michał Federowski's: Lud białoruski na Rusi Litewskiej. Analecta 2007, 16, 7-53.

14. Jabłonowska, M.; Mutryn, K.; Bazylko, A.; Grochowski, D.; Strawa, J.; Tomczyk, M. Identification of antioxidant polyphenolics from Jasione montana based on a preliminary LC-MS profiling. Planta Med. Inter. Open 2017, 4, S1-S202. [CrossRef]

15. Agrawal, P.K. Carbon-13 NMR of Flavonoids; Elsevier: Amsterdam, The Netherlands, 1989; ISBN 9781483290744.

16. Harborne, J.B. The Flavonoids. Advances in Research Since 1986.; Chapman \& Hall: London, UK, 1996.

17. Markham, K.R.; Ternai, B.; Stanley, R.; Geiger, H.; Mabry, T.J. Carbon-13 NMR studies of flavonoids-III. Tetrahedron 1978, 34, 1389-1397. [CrossRef]

18. Bruggisser, R.; von Daeniken, K.; Jundt, G.; Schaffner, W.; Tullberg-Reinert, H. Interference of plant extracts, phytoestrogens and antioxidants with the MTT tetrazolium assay. Planta Med. 2002, 68, 445-448. [CrossRef]

19. Wang, P.; Henning, S.M.; Heber, D. Limitations of MTT and MTS-based assays for measurement of antiproliferative activity of green tea polyphenols. PLoS ONE 2010, 5, e10202. [CrossRef] [PubMed]

20. Wisman, K.N.; Perkins, A.A.; Jeffers, M.D.; Hagerman, A.E. Accurate assessment of the bioactivities of redox-active polyphenolics in cell culture. J. Agric. Food Chem. 2008, 56, 7831-7837. [CrossRef] [PubMed]

21. Demchenko, A.P. Beyond annexin V: Fluorescence response of cellular membranes to apoptosis. Cytotechnology 2013, 65, 157-172. [CrossRef] [PubMed]

22. Bielawski, K.; Czarnomysy, R.; Muszyńska, A.; Bielawska, A.; Popławska, B. Cytotoxicity and induction of apoptosis of human breast cancer cells by novel platinum(II) complexes. Environ. Toxicol. Pharmacol. 2012, 35, 254-264. [CrossRef] [PubMed]

23. D'Arcy, M.S. Cell death: A review of the major forms of apoptosis, necrosis and autophagy. Cell Biol. Int. 2019, 43, 582-592. [CrossRef] [PubMed]

24. Bialik, S.; Dasari, S.K.; Kimchi, A. Autophagy-dependent cell death-Where, how and why a cell eats itself to death. J. Cell Sci. 2018, 131, jcs215152. [CrossRef]

25. Ly, J.D.; Grubb, D.R.; Lawen, A. The mitochondrial membrane potential $(\Delta \psi \mathrm{m})$ in apoptosis; an update. Apoptosis 2003, 8, 115-128. [CrossRef]

26. Green, D.R.; Kroemer, G. The pathophysiology of mitochondrial cell death. Science 2004, 305, 626-629. [CrossRef]

27. Sánchez-Alcázar, J.A.; Ault, J.G.; Khodjakov, A.; Schneider, E. Increased mitochondrial cytochrome c levels and mitochondrial hyperpolarization precede camptothecin-induced apoptosis in Jurkat cells. Cell Death Differ. 2000, 7, 1090-1100. [CrossRef]

28. Denault, J.-B.; Salvesen, G. Caspases: Keys in the ignition of cell death. Chem. Rev. 2003, 102, 4489-4500. [CrossRef] [PubMed]

29. Porter, A.G.; Jänicke, R.U. Emerging roles of caspase-3 in apoptosis. Cell Death Differ. 1999, 6, 99-104. [CrossRef] [PubMed]

30. Russo, M.; Mupo, A.; Spagnuolo, C.; Russo, G.L. Exploring death receptor pathways as selective targets in cancer therapy. Biochem. Pharmacol. 2010, 80, 674-682. [CrossRef] [PubMed]

31. Amin, A.R.M.R.; Kucuk, O.; Khuri, F.R.; Shin, D.M. Perspectives for cancer prevention with natural compounds. J. Clin. Oncol. 2009, 27, 2712-2725. [CrossRef] [PubMed]

32. Seelinger, G.; Merfort, I.; Wölfle, U.; Schempp, C.M. Anti-carcinogenic effects of the flavonoid luteolin. Molecules 2008, 13, 2628-2651. [CrossRef] [PubMed]

33. Ombra, M.N.; Paliogiannis, P.; Stucci, L.S.; Colombino, M.; Casula, M.; Sini, M.C.; Manca, A.; Palomba, G.; Stanganelli, I.; Mandalà, M.; et al. Dietary compounds and cutaneous malignant melanoma: Recent advances from a biological perspective. Nutr. Metab. 2019, 16, 1-15. [CrossRef]

34. Carradori, S.; D'Ascenzio, M.; Chimenti, P.; Secci, D.; Bolasco, A. Selective MAO-B inhibitors: A lesson from natural products. Mol. Divers. 2014, 18, 219-243. [CrossRef] [PubMed]

35. Juszczak, A.M.; Zovko-Končić, M.; Tomczyk, M. Recent trends in the application of chromatographic techniques in the analysis of luteolin and its derivatives. Biomolecules 2019, 9, 731. [CrossRef] [PubMed]

36. Szekalska, M.; Sosnowska, K.; Tomczykowa, M.; Winnicka, K.; Kasacka, I.; Tomczyk, M. In vivo anti-inflammatory and antiallergic activities of cynaroside evaluated by using hydrogel formulations. Biomed. Pharmacother. 2020, 121, 109681. [CrossRef]

37. Chan, K.T.; Meng, F.Y.; Li, Q.; Ho, C.Y.; Lam, T.S.; To, Y.; Lee, W.H.; Li, M.; Chu, K.H.; Toh, M. Cucurbitacin B induces apoptosis and $\mathrm{S}$ phase cell cycle arrest in BEL-7402 human hepatocellular carcinoma cells and is effective via oral administration. Cancer Lett. 2010, 294, 118-124. [CrossRef]

38. Lepley, D.M.; Li, B.; Birt, D.F.; Pelling, J.C. The chemopreventive flavonoid apigenin induces G2/M arrest in keratinocytes. Carcinogenesis 1996, 17, 2367-2375. [CrossRef] [PubMed]

39. Kim, J.K.; Kang, K.A.; Ryu, Y.S.; Piao, M.J.; Han, X.; Oh, M.C.; Boo, S.J.; Jeong, S.U.; Jeong, Y.J.; Chae, S.; et al. Induction of endoplasmic reticulum stress via reactive oxygen species mediated by luteolin in melanoma cells. Anticancer Res. 2016, 36, 2281-2289. [PubMed] 
40. Leung, H.W.-C.; Wu, C.-H.; Lin, C.-H.; Lee, H.-Z. Luteolin induced DNA damage leading to human lung squamous carcinoma CH27 cell apoptosis. Eur. J. Pharmacol. 2005, 508, 77-83. [CrossRef] [PubMed]

41. Fecker, L.; Geilen, C.; Hossini, A.; Schwarz, C.; Fechner, H.; Bartlett, D.; Orfanos, C.; Eberle, J. Selective induction of apoptosis in melanoma cells by tyrosinase promoter-controlled CD95 ligand overexpression. J. Invest. Dermatol. 2005, 124, 221-228. [CrossRef]

42. Said, A.; Tundis, R.; Hawas, U.W.; El-Kousy, S.M.; Rashed, K.; Menichini, F.; Bonesi, M.; Huefner, A.; Loizzo, M.R.; Menichini, F. In Vitro antioxidant and antiproliferative activities of flavonoids from Ailanthus excelsa (Roxb.) (Simaroubaceae) leaves. Z. Naturforsch C 2010, 65, 180-186. [CrossRef] [PubMed]

43. Visanji, J.M.; Thompson, D.G.; Padfield, P.J. Induction of G2/M phase cell cycle arrest by carnosol and carnosic acid is associated with alteration of cyclin A and cyclin B1 levels. Cancer Lett. 2006, 237, 130-136. [CrossRef]

44. Choi, E.J.; Kim, G.-H. O-desmethylangolensin inhibits the proliferation of human breast cancer MCF-7 cells by inducing apoptosis and promoting cell cycle arrest. Oncol. Lett. 2013, 6, 1784-1788. [CrossRef]

45. Zhang, J.; Zhu, X.; Li, H.; Li, B.; Sun, L.; Xie, T.; Zhu, T.; Zhou, H.; Ye, Z. Piperine inhibits proliferation of human osteosarcoma cells via G2/M phase arrest and metastasis by suppressing MMP-2/-9 expression. Int. Immunopharmacol. 2015, 24, 50-58. [CrossRef] [PubMed]

46. Czarnomysy, R.; Surazynski, A.; Popławska, B.; Rysiak, E.; Pawłowska, N.; Czajkowska, A.; Bielawski, K.; Bielawska, A. Synergistic action of cisplatin and echistatin in MDA-MB-231 breast cancer cells. Mol. Cell. Biochem. 2016, 427, 1-10. [CrossRef] [PubMed]

47. Shoshan-Barmatz, V.; Krelin, Y.; Chen, Q. VDAC1 as a player in mitochondria-mediated apoptosis and target for modulating apoptosis. Curr. Med. Chem. 2017, 24, 4435-4446. [CrossRef]

48. Green, D.R.; Reed, J.C. Mitochondria and apoptosis. Science 1998, 281, 1309-1312. [CrossRef]

49. Czarnomysy, R.; Surażyński, A.; Muszynska, A.; Gornowicz, A.; Bielawska, A.; Bielawski, K. A novel series of pyrazoleplatinum(II) complexes as potential anti-cancer agents that induce cell cycle arrest and apoptosis in breast cancer cells. J. Enzym. Inhib. Med. Chem. 2018, 33, 1006-1023. [CrossRef] [PubMed]

50. Danciu, C.; Zupko, I.; Bor, A.; Schwiebs, A.; Radeke, H.; Hancianu, M.; Cioanca, O.; Alexa, E.; Oprean, C.; Bojin, F.; et al. Botanical therapeutics: Phytochemical screening and biological assessment of chamomile, parsley and celery extracts against A375 human melanoma and dendritic cells. Int. J. Mol. Sci. 2018, 19, 3624. [CrossRef] [PubMed]

51. Cattaneo, L.; Cicconi, R.; Mignogna, G.; Giorgi, A.; Mattei, M.; Graziani, G.; Ferracane, R.; Grosso, A.; Aducci, P.; Schininà, M.E.; et al. Anti-proliferative effect of Rosmarinus officinalis L. extract on human melanoma A375 cells. PLoS ONE 2015, 10, 1-18. [CrossRef] [PubMed]

52. Corazzari, M.; Fimia, G.M.; Lovat, P.; Piacentini, M. Why is autophagy important for melanoma? Molecular mechanisms and therapeutic implications. Semin. Cancer Biol. 2013, 23, 337-343. [CrossRef] [PubMed]

53. Liu, H.; He, Z.; Simon, H.-U. Targeting autophagy as a potential therapeutic approach for melanoma therapy. Semin. Cancer Biol. 2013, 23, 352-360. [CrossRef]

54. Thorburn, A.; Thamm, D.H.; Gustafson, D.L. Autophagy and cancer therapy. Mol. Pharmacol. 2014, 85, 830-838. [CrossRef]

55. Chu, Y.-L.; Raghu, R.; Lu, K.-H.; Liu, C.-T.; Lin, S.-H.; Lai, Y.-S.; Cheng, W.-C.; Lin, S.-H.; Sheen, L.-Y. Autophagy therapeutic potential of garlic in human cancer therapy. J. Tradit. Complement. Med. 2013, 3, 159-162. [CrossRef] [PubMed]

56. Zhao, G.; Han, X.; Zheng, S.; Li, Z.; Sha, Y.; Ni, J.; Sun, Z.; Qiao, S.; Song, Z. Curcumin induces autophagy, inhibits proliferation and invasion by downregulating AKT/mTOR signaling pathway in human melanoma cells. Oncol. Rep. 2016, 35, 1065-1074. [CrossRef] [PubMed]

57. Yang, S.-F.; Yang, W.-E.; Chang, H.-R.; Chu, S.-C.; Hsieh, Y.-S. Luteolin induces apoptosis in oral squamous cancer cells. J. Dent. Res. 2008, 87, 401-406. [CrossRef]

58. Zhang, Q.; Zhao, X.-H.; Wang, Z.-J. Flavones and flavonols exert cytotoxic effects on a human oesophageal adenocarcinoma cell line (OE33) by causing G2/M arrest and inducing apoptosis. Food Chem. Toxicol. 2008, 46, 2042-2053. [CrossRef] [PubMed]

59. Lim, D.Y.; Jeong, Y.; Tyner, A.L.; Park, J.H.Y. Induction of cell cycle arrest and apoptosis in HT-29 human colon cancer cells by the dietary compound luteolin. Am. J. Physiol. Gastrointest. Liver Physiol. 2007, 292, G66-G75. [CrossRef]

60. Selvendiran, K.; Koga, H.; Ueno, T.; Yoshida, T.; Maeyama, M.; Torimura, T.; Yano, H.; Kojiro, M.; Sata, M. Luteolin promotes degradation in signal transducer and activator of transcription 3 in human hepatoma cells: An implication for the antitumor potential of flavonoids. Cancer Res. 2006, 66, 4826-4834. [CrossRef]

61. Strawa, J.; Wajs-Bonikowska, A.; Jakimiuk, K.; Waluk, M.; Poslednik, M.; Nazaruk, J.; Tomczyk, M. Phytochemical examination of woolly burdock Arctium tomentosum leaves and flower heads. Chem. Nat. Compd. 2020, 56, 345-347. [CrossRef]

62. Nazaruk, J. Flavonoid compounds from Cirsium palustre (L.) Scop. flower heads. Biochem. Syst. Ecol. 2009, 37, 525-527. [CrossRef]

63. Carmichael, J.; DeGraff, W.; Gazdar, A.; Minna, J.; Mitchell, J. Evaluation of a tetrazolium-based semiautomated colorimetric assay: Assessment of radiosensitivity. Cancer Res. 1987, 47, 943-946. 